Article

\title{
Comparison of Gross Primary Productivity Derived from GIMMS NDVI3g, GIMMS, and MODIS in Southeast Asia
}

\author{
Junbang Wang ${ }^{1}$, Jingwei Dong ${ }^{2}{ }_{*}$, Jiyuan Liu ${ }^{1}$, Mei Huang ${ }^{1{ }_{*}}$, Guicai $\mathrm{Li}^{3}$, \\ Steven W. Running ${ }^{4}$, W. Kolby Smith ${ }^{4}$, Warwick Harris ${ }^{5}$, Nobuko Saigusa ${ }^{6}$, \\ Hiroaki Kondo ${ }^{7}$, Yunfen Liu ${ }^{1}$, Takashi Hirano ${ }^{8}$ and Xiangming Xiao ${ }^{2}$
}

1 Key Laboratory of Ecosystem Network Observation and Modeling, Institute of Geographic Sciences and Natural Resources Research, Chinese Academy of Sciences, Beijing 100101, China; E-Mails: jbwang@igsnrr.ac.cn (J.W.); liujy@igsnrr.ac.cn (J.L.); liuyf@igsnrr.ac.cn (Y.L.)

2 Department of Microbiology and Plant Biology, and Center for Spatial Analysis, University of Oklahoma, Norman, OK 73019, USA; E-Mail: xiangming.xiao@ ou.edu

3 National Satellite Meteorological Center, China Meteorological Administration, Beijing 100101, China; E-Mail: ligc@cma.gov.cn

4 Numerical Terradynamic Simulation Group, College of Forestry and Conservation, University of Montana, 32 Campus Drive, Missoula, MT 59812, USA; E-Mails: swr@ntsg.umt.edu (S.W.R.); bill.smith@ntsg.umt.edu (W.K.S.)

5 Landcare Research, P.O. Box 69040, Lincoln 7640, New Zealand; E-Mail: harrisw@landcareresearch.co.nz

6 Center for Global Environmental Research, National Institute for Environmental Studies, 16-2 Onogawa, Tsukuba Ibaraki 305-8506, Japan; E-Mail: n.saigusa@nies.go.jp

7 Research Institute for Environmental Management Technology, National Institute of Advanced Industrial Science and Technology, 16-1 Onogawa, Tsukuba 305-8569, Japan;

E-Mail: kondo-hrk@aist.go.jp

8 Research Faculty of Agriculture, Hokkaido University, Sapporo 060-8589, Japan; E-Mail: hirano@env.agr.hokudai.ac.jp

* Authors to whom correspondence should be addressed; E-Mails: jinwei.dong@ ou.edu (J.D.); huangm@igsnrr.ac.cn (M.H.); Tel.: +86-10-6487-4229 (M.H.); Fax: +86-10-6485-4230 (M.H.).

Received: 14 June 2013; in revised form: 4 February 2014 / Accepted: 19 February 2014 / Published: 7 March 2014

Abstract: Gross primary production (GPP) plays an important role in the net ecosystem exchange of $\mathrm{CO}_{2}$ between the atmosphere and terrestrial ecosystems. It is particularly important to monitor GPP in Southeast Asia because of increasing rates of tropical forest 
degradation and deforestation in the region in recent decades. The newly available, improved, third generation Normalized Difference Vegetation Index (NDVI3g) from the Global Inventory Modelling and Mapping Studies (GIMMS) group provides a long temporal dataset, from July 1981 to December 2011, for terrestrial carbon cycle and climate response research. However, GIMMS NDVI3g-based GPP estimates are not yet available. We applied the GLOPEM-CEVSA model, which integrates an ecosystem process model and a production efficiency model, to estimate GPP in Southeast Asia based on three independent results of the fraction of photosynthetically active radiation absorbed by vegetation (FPAR) from GIMMS NDVI3g (GPP NDVI3g $)$, GIMMS NDVI1g $\left(\mathrm{GPP}_{\text {NDVIIg }}\right)$, and the Moderate

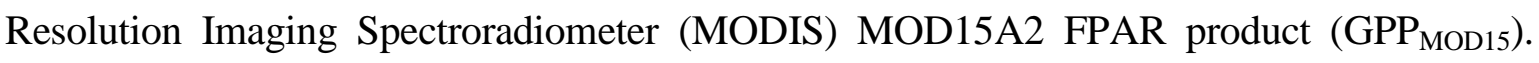
The GPP results were validated using ground data from eddy flux towers located in different forest biomes, and comparisons were made among the three GPPs as well as the MOD17A2 GPP products $\left(\mathrm{GPP}_{\mathrm{MOD17}}\right)$. Based on validation with flux tower derived GPP estimates the results show that $\mathrm{GPP}_{\mathrm{NDVI} g}$ is more accurate than $\mathrm{GPP}_{\mathrm{NDVII}}$ and is comparable in accuracy with GPP $\mathrm{MOD15}_{\text {. In addition, } \mathrm{GPP}_{\mathrm{NDV} \text { I3g }} \text { and GPP }}$ MOD15 have good spatial-temporal consistency. Our results indicate that GIMMS NDVI3g is an effective dataset for regional GPP simulation in Southeast Asia, capable of accurately tracking the variation and trends in long-term terrestrial ecosystem GPP dynamics.

Keywords: Gross Primary Productivity (GPP); GIMMS NDVI3g; GLOPEM-CEVSA; GIMMS NDVI1g; MOD15A2; MOD17A2; Southeast Asia

\section{Introduction}

Gross primary production (GPP) is an essential flux of the net ecosystem exchange (NEE) of $\mathrm{CO}_{2}$ between the atmosphere and terrestrial ecosystems, and contributes to human welfare by regulating ecosystem functions [1-4]. Estimates of the magnitude and variability of GPP and NEE are fundamental to understanding the biogeochemical dynamics of terrestrial ecosystems [5,6]. Since the 1990s, the eddy covariance method has emerged as an important tool to investigate seasonal phasing and amplitudes of $\mathrm{CO}_{2}$ fluxes between terrestrial ecosystems and the atmosphere [4,7]. The net carbon fluxes from eddy covariance towers can be partitioned into the components GPP and ecosystem respiration (RE), which can be used to validate products developed by biogeochemical models and remotely sensed vegetation indices $[4,8]$. However, it is a challenging task to extrapolate GPP and $\mathrm{CO}_{2}$ flux measurements to the large scale due to significant spatial and temporal heterogeneity of ecosystems across complex landscapes.

Two main methods exist for deriving large-scale estimates of GPP [9-11]: (1) the application of process-based, biogeochemical models that scale-up and extrapolate site-specific measurements [12-14]; and (2) the application of satellite data based on the concept of light use efficiency [9,15-29]. The accuracy of satellite-derived GPP or NPP estimates have been recently highlighted as a matter of concern due to poor satellite data quality as well as lack of accurate ecosystem representation in satellite-based models [30]. In our previous work, an integrated strategy was presented that combined 
the remote sensing-based GLObal Production Efficiency Model (GLOPEM) and the ecosystem process-based model, the Carbon Exchange between Vegetation, Soil and Atmosphere model (CEVSA). The integrated GLOPEM-CEVSA model was shown to increase the accuracy of spatial and temporal estimates of terrestrial ecosystem GPP, RE, and NEE by taking into consideration the spatial heterogeneity of ecosystems [9]. The model was also shown to be suitable for estimating the spatial-temporal distribution of net primary production (NPP) for forest and grassland ecosystems [31,32].

A main component of the GLOPEM-CEVSA modeling framework is the satellite-derived fraction of photosynthetically active radiation absorbed by vegetation (FPAR), which can be derived from satellite normalized difference vegetation index (NDVI) data. The Advanced Very High Resolution Radiometer (AVHRR) sensor has the longest record of continuous satellite data, spanning 1981 to the present, and the data have been used to produce various versions of the GIMMS (Global Inventory Modeling and Mapping Studies) NDVI data product. For example, the previous GIMMS NDVI dataset has been widely used by the community [33] (GIMMS NDVI1g, hereafter). The newest version of the global GIMMS NDVI dataset version 3, termed NDVI3g, has been recently released and covers 31 years from July 1981-2011 with data sensed by AVHRR onboard NOAA 7, 9, 11,14, 16, 17 and 18 [34,35]. NDVI3g represents an important advance by extending the satellite record to more than 30 years. NDVI3g is a global product with a bi-monthly temporal resolution and $\sim 8-\mathrm{km}$ spatial resolution, and features improved data quality by accounting for biases such as calibration loss, orbital drift, volcanic eruptions, etc. [36]. Further, NDVI3g data has been previously shown to represent real responses of vegetation to climate variability [37]; suggesting that significant potential exists for the NDVI3g dataset to contribute to long-term simulations of GPP.

Our main objective here was to compare the newly available GIMMS NDVI3g dataset to similar existing data products in an effort to establish the potential for GIMMS NDVI3g to advance understanding of the terrestrial carbon cycle for the region of Southeast Asia. First, we simulated GPP using the GLOPEM-CEVSA model, the same meteorological datasets, and various FPAR products from GIMMS NDVI3g, GIMMS NDVI1g, and the Moderate Resolution Imaging Spectroradiometer (MODIS) FPAR product (MOD15A2). Second, we validated the derived GPP estimates using the eddy covariance derived GPP data and conducted a comparison among the three GPP results as well as the MODIS primary production products (MOD17A2). With this study, we aim to set the stage for the first continuous 30-year records of GPP for Southeast Asia, which we hope to use to improve our understanding of the climatic and anthropogenic responses of ecosystems that have occurred in the region over the previous three decades.

\section{Method and Data}

\subsection{Models}

\subsubsection{GLOPEM-CEVSA}

GLOPEM-CEVSA represents a coupling of two independently developed models (GLO-PEM and CEVSA), and describes the processes and mechanisms of an ecosystem based on remotely sensed vegetation indices and the simulation of the physiological processes (Figure 1) $[9,32]$. Founded on the concept of production efficiency, the GLO-PEM model uses satellite remote sensing data to estimate 
GPP and NPP [22,38,39]. The GLO-PEM approach has previously been applied successfully at both the regional and global scale [22,40-43]. The CEVSA model is an ecosystem process and mechanism model developed to describe the carbon cycles of terrestrial ecosystems. CEVSA has been applied to simulate net ecosystem productivity (NEP) at the regional and global scale [44-46]. The combination of these models, the GLOPEM-CEVSA model, can thus simulate GPP, NPP, and NEP. Here, we mainly focus on the evaluation of the GPP product as it is impacted by FPAR data from different sources.

Figure 1. Framework of the GLOPEM-CEVSA model. GLOPEM-CEVSA represents the coupling of the GLObal Production Efficiency Model (GLO-PEM, shown by solid lines) with the Carbon Exchange between Vegetation, Soil and Atmosphere (CEVSA) model (shown by dashed lines). A detailed description of this model is available in [9,32].

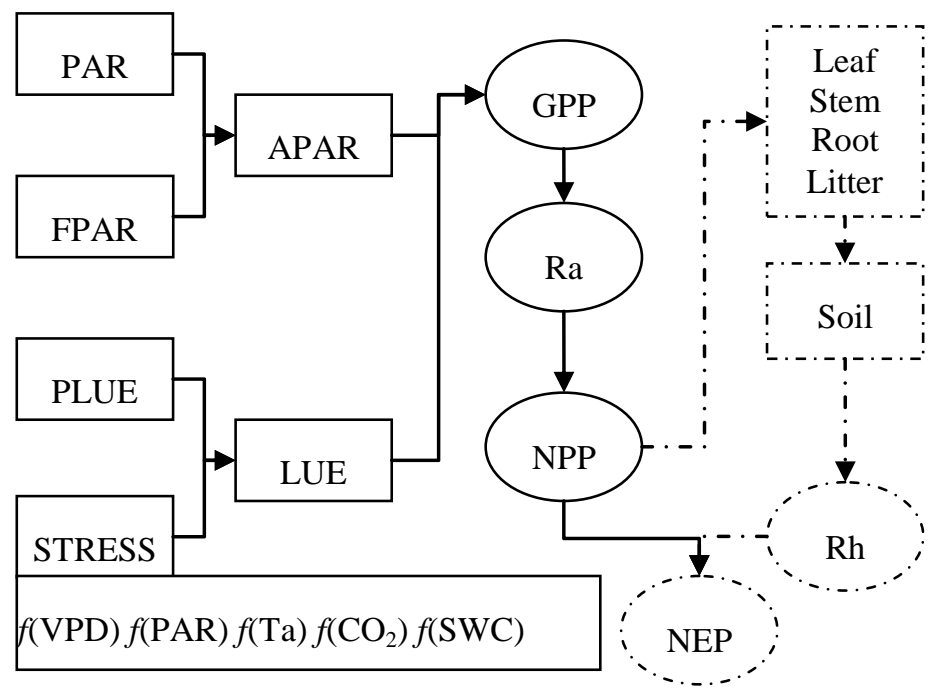

\begin{abstract}
Abbreviations: GPP: gross primary production; Ra: autotrophic respiration of vegetation; NPP: net primary production; Rh: heterogeneity respiration in soil; NEP: net ecosystem production; FPAR: fraction of photosynthetically active radiation absorbed by the vegetation; PLUE: potential conversion efficiency or carbon yield of absorbed energy in terms of GPP; LUE: actual light use efficiency under environmental stress; VPD: air vapor pressure deficit; PAR: photosynthetically active radiation; Ta: air temperature; $\mathrm{CO}_{2}$ : atmospheric carbon dioxide concentration; SWC: soil water content
\end{abstract}

According to production efficiency logic, we estimated GPP by assuming a linear relationship between the incoming photosynthetically active radiation (PAR), the fraction of PAR absorbed by the vegetation (FPAR), the potential conversion efficiency or carbon yield of absorbed energy $\left(\varepsilon^{*}\right)$, and the reduction of $\varepsilon^{*}$ caused by environmental factors $(\sigma)$ (Equation $\left.(1)\right)[9,22,43]$.

$$
G P P=P A R \times F P A R \times \varepsilon^{*} \times \sigma
$$

GLO-PEM and the newly developed GLOPEM-CEVSA model differ from other production efficiency models in that these models do not assign a fixed value for potential light use efficiency for each vegetation type. Instead, they are based on quantum yield that is affected by, among other factors, photosynthetic pathway, temperature, and the $\mathrm{CO}_{2} / \mathrm{O}_{2}$ specificity ratio $[22,43,47]$, which are given in Appendix. We estimated $\sigma$ using critical environmental factors known to impact stomatal conductance [43], according to the below equation: 


$$
\sigma=f(T) \times f\left(\delta_{q}\right) \times f\left(\delta_{\theta}\right)
$$

where $f(T), f\left(\delta_{q}\right)$ and $f\left(\delta_{\theta}\right)$, respectively, represent the effects of air temperature $(T)$, specific humidity deficit $\left(\delta_{q}\right)$, and soil moisture $\left(\delta_{\theta}\right)$ on stomatal conductance [43]. The temperature effect, $f(T)$, reaches the maximum (1.0) at the optimum temperature and tapers off for warmer or cooler temperatures [48]:

$$
f(T)=\frac{\left(T-T_{\min }\right)\left(T-T_{\max }\right)}{\left(T-T_{\min }\right)\left(T-T_{\max }\right)-\left(T-T_{\text {opt }}\right)^{2}}
$$

where $T$ is air temperature $\left({ }^{\circ} \mathrm{C}\right)$ and $T_{\min }, T_{\text {opt }}$ and $T_{\max }$ are respectively the minimum, optimum and maximum temperatures $\left({ }^{\circ} \mathrm{C}\right)$.

$$
\begin{gathered}
f\left(\delta_{q}\right)=\left\{\begin{array}{cc}
1-0.05 \delta_{q} & 0<\delta_{q} \leq 15 \\
0.25 & \delta_{q}>15
\end{array}\right. \\
\delta_{q}=\mathrm{Qw}(T)-q
\end{gathered}
$$

where $\delta_{q}$ is the specific humidity deficit $\left(\mathrm{g} \mathrm{kg}^{-1}\right), \mathrm{Qw}(T)$ is the saturated specific humidity at the air temperature, and $q$ is the specific humidity of the air. The effect of soil moisture is given as:

$$
f\left(\delta_{\theta}\right)=1-\exp \left(0.081\left(\delta_{\theta}-83.03\right)\right.
$$

where $\delta_{\theta}$ is the soil moisture deficit $(\mathrm{mm})$ in the top $1.0 \mathrm{~m}$ of soil. The soil moisture deficit is defined as the difference between saturated water content and actual water content, which is calculated with the algorithms described in [21].

\subsubsection{The MODIS Algorithm (MOD17)}

As the first regular, near-real-time data sets for repeated monitoring of vegetation primary production on vegetated land at $1-\mathrm{km}$ resolution and an eight-day interval [25,49,50], the MODIS primary production products were applied for comparison with GIMMS NDVI3g based GPP. The MODIS algorithm (MOD17) also uses the concept of the light use efficiency. In the model, the actual light use efficiency $(\varepsilon)$ calculation includes two parts: (1) the biome-level maximum light use efficiency estimate and (2) the environmental stress scalars:

$$
\varepsilon=\varepsilon_{\max } \times T M I N_{\text {scalar }} \times V P D_{\text {scalar }}
$$

The potential light use efficiency $\left(\varepsilon_{\mathrm{max}}\right)$ is optimized in advance with a complex ecosystem model, BIOME-BGC, and is given in a Biome Parameter Look-up Table (BPLUT) for each land cover type in the PSN model. The $T M I N_{\text {scalar }}$ and $V P D_{\text {scalar }}$ are environmental stress factors and are parameterized according to Equations (7) and (8):

$$
\begin{aligned}
& \text { TMIN }_{\text {scalar }}=\left\{\begin{array}{cc}
1 & T M I N<T M I N_{\max } \\
\left(T M I N-T M I N_{\min }\right) /\left(T M I N_{\max }-T M I N_{\min }\right) & T M I N_{\min }<T M I N<T M I N_{\max } \\
0 & T M I N>T M I N_{\min }
\end{array}\right. \\
& V P D_{\text {scalar }}=\left\{\begin{array}{cc}
1 & V P D<V P D_{\max } \\
\left(V P D-V P D_{\min }\right) /\left(V P D_{\max }-V P D_{\min }\right) & V P D_{\min }<V P D<V P D_{\max } \\
0 & V P D>V P D_{\min }
\end{array}\right.
\end{aligned}
$$

where TMIN and VPD are the daily minimum temperature $\left({ }^{\circ} \mathrm{C}\right)$ and average vapor pressure deficit $(\mathrm{Pa})$, $T M I N_{\max }$ and $V P D_{\max }$ are the daily minimum temperature and average vapor pressure deficit at which 
$\varepsilon=\varepsilon_{\max }$, and $T M I N_{\min }$ and $V P D_{\min }$ are the daily minimum temperature and average vapor pressure deficit at which $\varepsilon=0$. These parameters were determined for each land cover type in the BPLUT.

The main data inputs into the MOD17 model include: (1) FPAR and LAI from the MODIS MOD15 LAI/FPAR data products; (2) temperature, incoming solar radiation, and vapor pressure deficit from NCEP/DOE reanalysis II [51]; (3) land cover classification from the MODIS MCD12Q1 data product; and (4) a Biome Parameter Look-up Table (BPLUT) containing values of $\varepsilon_{\max }$ and other biome-specific physiological parameters for different vegetation types.

\subsection{Main Data for GLOPEM-CEVSA Model Input and Validations}

The GLOPEM-CEVSA model inputs include the interpolated meteorological data, the remote sensed FPAR and vegetation classification data, and soil data (e.g., soil texture, soil available water and soil carbon). Other auxiliary data included digital elevation model (DEM) data and vegetation carbon storage data.

The DEM was used in the meteorological data interpolation, and was obtained from Shuttle Radar Topography Mission (SRTM) with an original 90-m spatial resolution and was resampled to 8-km resolution. Soil texture and soil carbon storage were obtained from the Harmonized World Soil Database (HWSD) of the International Institute of Applied System Analysis (IIASA) and the Food and Agriculture Organization (FAO). The soil carbon storage data was used to initialize the soil respiration sub-module, and the soil texture data was used to calculate the parameters of soil water content.

\subsubsection{Meteorological Data}

The meteorological data needed for GLOPEM-CEVSA included the interpolated air temperature, precipitation, wind speed, air relative humidity, and radiance data. In this study, the air relative humidity was calculated with the dew temperature and air temperature according to Allen [52]. The air temperature, dew temperature and wind speed were the Global Surface summary Of Day Data (GSOD) produced by the National Climatic Data Center (NCDC). The eight-day mean was calculated with the daily observations of the station from 1980-2008 and then interpolated to an eight-day grid with 8-km spatial resolution. The ANUSPLIN package (version 4.2), that is based on thin plate smoothing splines of multi-variates, was applied for interpolation in this study because of its good performance compared to other interpolation methods [53].

The daily precipitation datasets were derived from the Asian Precipitation Highly-Resolved Observational Data Integration Towards Evaluation of Water Resources (APHRODITE's Water Resources) project [54]. We used the dataset in the Monsoon Asia area from 1980-2007 and as precipitation showed spatial discontinuity, we re-projected and resampled from $0.25^{\circ}$ to 8 - $\mathrm{km}$ using the nearest neighbour algorithm. The Surface Radiation Budget (SRB) Release 3.0 daily data for 1984-2007 were obtained from the NASA Langley Research Center Atmospheric Sciences Data Center NASA/GEWEX SRB Project. The SRB dataset is a daily global product with $1^{\circ} \times 1^{\circ}$ resolution and it was resampled to $8-\mathrm{km}$ spatial resolution with the bilinear algorithm as radiation data showed good spatial continuity. Then, the photosynthetically active radiation and net radiation were calculated with the all-sky surface downward and upward shortwave flux. 


\subsubsection{Remotely Sensed Data}

\section{(1) GIMMS FPAR}

FPAR was linearly related with NDVI or the NDVI-derived Simple Ratio (SR, $S R=(1+N D V I) /(1-N D V I))$. Previous study has shown that the NDVI-based FPAR model $\left(F P A R_{N D V I}\right)$ and SR-based FPAR model $\left(F P A R_{S R}\right)$ can overestimate or underestimate FPAR respectively, and an integrated model by combining $F P A R_{N D V I}$ and $F P A R_{S R}$ would provide an improved estimate [55]. We used this integrated strategy to calculate the FPAR,

$$
F P A R=\alpha F P A R_{N D V I}+(1-\alpha) F P A R_{S R}
$$

where $\alpha$ was arbitrarily set to 0.5 . We calculated the FPAR $_{\mathrm{SR}}$ by using this empirical algorithm [35] that is for a horizontally homogeneous, closed canopy composed almost exclusively of green material,

$$
F P A R_{S R}=\frac{\left(S R-S R_{i, \min }\right)\left(F P A R_{\max }-F P A R_{\text {min }}\right)}{\left(S R_{i, \text { max }}-S R_{i, \text { min }}\right)}+F P A R_{\min }
$$

where $S R_{\max }$ and $S R_{\min }$ are the simple ratios corresponding to the $98 \%$ and $2 \%$ of the NDVI frequency distributions of the $i$ vegetation type. The 98\% NDVI is assumed to represent vegetation with the maximum FPAR value, $F P A R_{\max }$, here assumed to be 0.95 ; the $2 \%$ value is assumed to represent no vegetation cover and is assumed to correspond to a FPAR value close to $0, F P A R_{\min }$, here was assumed to be 0.001 [35]. NDVI-based FPAR was calculated by the following empirical equation,

$$
F P A R_{N D V I}=\frac{\left(N D V I-N D V I_{i, \min }\right)\left(F P A R_{\max }-F P A R_{\min }\right)}{\left(N D V I_{i, \text { max }}-N D V I_{i, \min }\right)}+F P A R_{\min }
$$

where the $N D V I_{\max }$ and $N D V I_{\min }$ were estimated as 0.96 and 0.03 corresponding to the $98 \%$ and $2 \%$ thresholds of the NDVI frequency distributions of all the vegetated area. In order to match with MODIS data, the GIMMS FPAR was interpolated from the half month time step to the eight-day step by the spline algorithms in Matlab [56].

\section{(2) MODIS FPAR}

The MOD15A2 FPAR is retrieved from the reflectance of two bands (648 and $858 \mathrm{~nm}$ ) and its algorithm is based on three-dimensional radiative transfer theory and a back-up method based on relations between the NDVI and LAI/FPAR [57-61]. The FPAR data were downloaded from the Land Processes Distributed Active Archive Center (LP DAAC) [62], then filtered to remove the noise in FPAR time series by using the adaptive Savitzky-Golay (SG) method in the TIMESAT software [62,63]. The results had a $1-\mathrm{km}$ spatial resolution and were resampled to $8-\mathrm{km}$. We will refer to this processed

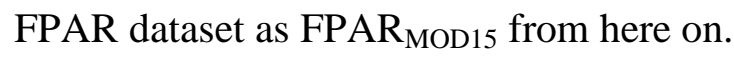




\section{(3) Land Cover}

The MODIS land cover product (MOD12Q1) was applied as the vegetation classification data in this study (Figure 2). This product provides global land cover maps at 1-km spatial resolution principally using the International Geosphere-Biosphere Programme (IGBP) classification systems [64]. To match with the other datasets used in this study, MOD12Q1 data was resampled from 1-km spatial resolution to 8-km with the nearest neighbour algorithm.

Figure 2. The vegetation classification map according to the MODIS land cover product (MOD12Q1). The locations of the flux tower sites used to assess the remote sensing based FPAR and GPP in this study are also shown as symbols. More detailed descriptions of the eight sites are given in Table 1.

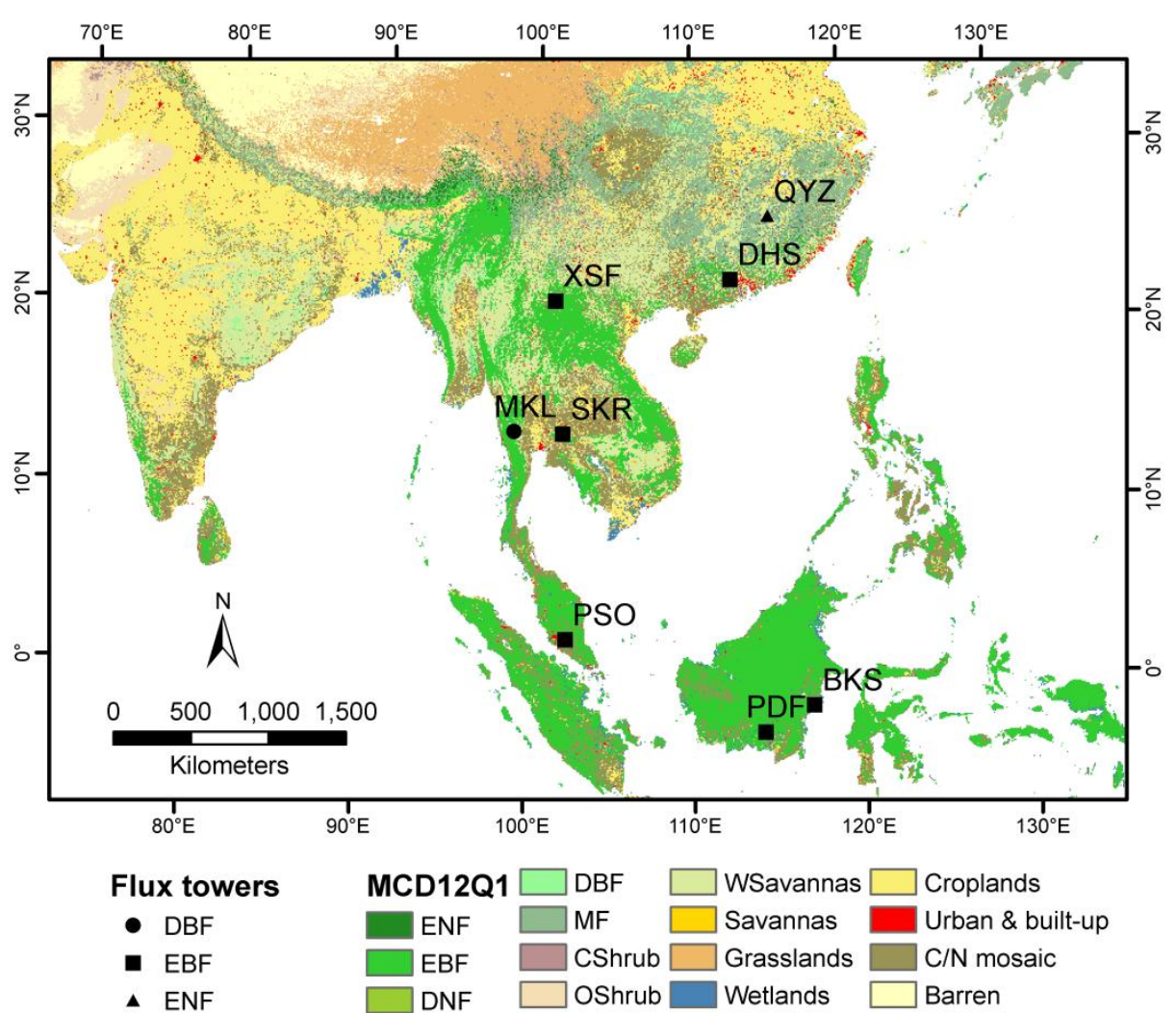

Vegetation types: ENF: Evergreen Needleleaf Forest; EBF: Evergreen Broadleaf Forest; DNF: Deciduous Needleleaf Forest; DBF: Deciduous Broadleaf Forest; MF: Mixed Forest; CShrub: Closed Shrub; OShrub: Open Shrub; Wsavannas: Wood Savannas; C/N mosaic: Cropland and Natural vegetation mosaic.

\subsubsection{Validation and Comparison of the Derived GPPs}

The observations for eight forest sites across Southeast Asia (Table 1 [65-74], Figure 2) were used to assess the performance of the modeled GPP and the remote sensing based FPAR in this study. 
Table 1. Description of the eddy covariance towers used for the GPP validation. The daily GPP was available from the Qianyanzhou (QYZ) site in the ChinaFlux Network and the Palangkaraya (PDF) site in the AsiaFlux Network. Annual GPPs are from the references listed for the eight sites.

\begin{tabular}{|c|c|c|c|c|c|c|c|}
\hline $\begin{array}{c}\text { Site name } \\
\text { (Site Code), Country }\end{array}$ & $\begin{array}{l}\text { Latitude and } \\
\text { Longitude }\left({ }^{\circ}\right)\end{array}$ & $\begin{array}{c}\text { Elevation } \\
(\mathbf{m}) \\
\end{array}$ & Forest Type & $\begin{array}{c}\text { Annual } \\
\text { Mean T }\left({ }^{\circ} \mathbf{C}\right) \\
\end{array}$ & $\begin{array}{c}\text { Annual } \\
\text { Precipitation (mm) } \\
\end{array}$ & Period & References \\
\hline $\begin{array}{l}\text { Qianyanzhou (QYZ), } \\
\text { China }\end{array}$ & $26.73,115.07$ & 102 & $\begin{array}{l}\text { Subtropical } \\
\text { evergreen conifer } \\
\text { plantation }\end{array}$ & 18 & 1485 & 2003-2005 & {$[65,66]$} \\
\hline $\begin{array}{l}\text { Dinghushan (DHS), } \\
\text { China }\end{array}$ & $23.17,112.53$ & $100-700$ & $\begin{array}{l}\text { Subtropical } \\
\text { evergreen broadleaf } \\
\text { forest }\end{array}$ & 21 & 1700 & 2003-2009 & {$[67,68]$} \\
\hline $\begin{array}{l}\text { Xishuangbanna } \\
\text { (XSF), China }\end{array}$ & $21.93,101.27$ & 750 & Tropical rain forest & 22 & 1487 & $2003-2008$ & [69] \\
\hline $\begin{array}{l}\text { Mae Klong } \\
\text { (MKL), Thailand }\end{array}$ & $14.57,98.83$ & 160 & $\begin{array}{l}\text { Tropical seasonal } \\
\text { deciduous forest }\end{array}$ & 25 & 1200 & 2003-2004 & {$[70,71]$} \\
\hline $\begin{array}{l}\text { Sakaerat (SKR), } \\
\text { Thailand }\end{array}$ & $14.48,101.90$ & 535 & $\begin{array}{l}\text { Tropical dry } \\
\text { evergreen forest }\end{array}$ & 24 & 1500 & $2002-2003$ & {$[70,71]$} \\
\hline $\begin{array}{l}\text { Pasoh Forest Reserve } \\
\text { (PSO), Malaysia }\end{array}$ & $2.97,102.30$ & $75-150$ & Tropical rain forest & 26 & 1700 & 2003-2005 & {$[70,71]$} \\
\hline $\begin{array}{l}\text { Bukit Soeharto } \\
\text { (BKS), Indonesia }\end{array}$ & $-0.86,117.04$ & 20 & $\begin{array}{l}\text { Tropical secondary } \\
\text { forest }\end{array}$ & 27 & 3300 & 2002 & {$[70,72]$} \\
\hline $\begin{array}{l}\text { Palangkaraya drained } \\
\text { forest (PDF), Indonesia }\end{array}$ & $-2.35,114.03$ & 30 & $\begin{array}{l}\text { Tropical peat swamp } \\
\text { forest }\end{array}$ & 26 & 2540 & 2004-2008 & {$[70,73,74]$} \\
\hline
\end{tabular}

(1) GPP Validation Data

GPP validation was conducted for two levels: (1) seasonal variability using the daily GPP data from the Qianyanzhou (QYZ) site of ChinaFlux and the Palangkaraya (PDF) site of AsiaFlux; (2) annual GPP magnitude with data derived from the literature for eight flux towers (Table 1).

The eddy covariance observations began in 2002 at the QYZ Forest Station, Jiangxi province, China $\left(26^{\circ} 45^{\prime} 16.0^{\prime \prime} \mathrm{N}, 115^{\circ} 4^{\prime} 15.0^{\prime \prime} \mathrm{E}\right)$ [65,75]. It has a typical subtropical monsoon climate and the dominant species are masson pine (Pinus massoniana), slash pine (Pinus elliottii) and Chinese fir (Cunninghamia lanceolata) planted in 1984 and 1985 [65,75-77]. The quality of the measured turbulence flux over this hilly region was evaluated and the fluctuation in $\mathrm{CO}_{2}$ density caused by temperature and water vapor variations was corrected [66]. Mean diurnal variations and nonlinear regression were used in the gap-filling of the missing observations [65]. RE was estimated from the relationship between the nighttime NEE and temperature, then GPP was estimated from NEE and RE $[65,78,79]$.

The eddy covariance tower PDF is located near Palangkaraya, Indonesia $\left(2^{\circ} 20^{\prime} 42^{\prime \prime} \mathrm{S}, 114^{\circ} 2^{\prime} 11^{\prime \prime} \mathrm{E}\right.$, $30 \mathrm{~m}$ above sea level). The site is tropical and has clear wet and dry seasons, with the dry season lasting from May or June to October or November. The vegetation type is tropical peat swamp evergreen forest with Combretocarpus rotundatus, Cratoxylum arborescens, Buchanania sessifolia and Tetramerista glabra as the dominant species. The area of the forest is $>50 \mathrm{~km}^{2} . \mathrm{CO}_{2}$ and energy 
fluxes have been measured there since November 2001 using the eddy covariance technique with a sonic anemometer-thermometer (CSAT3; Campbell Scientific Inc., Logan, UT, USA) and an open-path $\mathrm{CO}_{2} / \mathrm{H}_{2} \mathrm{O}$ analyzer (LI7500; Li-Cor Inc., Lincoln, NE, USA) at $41.3 \mathrm{~m}$ height, about $15 \mathrm{~m}$ above the forest canopy. More details are given in Reference [80].

(2) Methods of Validation and Their Comparison

The GPP estimations from the three FPAR products $\left(\mathrm{GPP}_{\mathrm{NDVI} g}, \mathrm{GPP}_{\mathrm{NDVII}}\right.$, and $\left.\mathrm{GPP}_{\mathrm{MOD} 15}\right)$ were validated and evaluated with the GPP from the eddy towers. They were also compared with the MODIS GPP product MOD17A2 (GPP $\left.{ }_{\text {MOD17 }}\right)$ [25,49]. All three GPP products were simulated using the same climatic data input and different FPAR datasets from the GIMMS NDVI3g (FPAR ${ }_{\text {NDVI3g }}$ ), the

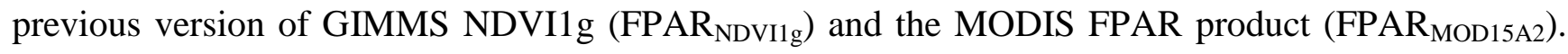
This allowed comprehensive exploration of the reasons for GPP differences.

Linear regression analysis was applied to evaluate the performance of the remote sensed GPP and FPAR with reference to the on-ground observed GPP. Correlation coefficient $r$, adjusted coefficient of determination $R^{2}, P$-value of a standard $T$-test statistic $p$, and sample size were used to define accuracy statistically. We also applied Root-mean-square error (RMSE) and relative RMSE to quantify the errors of the remote sensing based GPPs.

\section{Results}

\subsection{GPP Assessments on Seasonal Scale}

According to an eight-day interval GPP analysis shown in Figures 3 and 4, the seasonal changes of the modeled GPPs $\left(\mathrm{GPP}_{\mathrm{NDVI}}\right.$, $\mathrm{GPP}_{\mathrm{NDVI1}}$, GPP $\mathrm{MOD15}_{\mathrm{M}}$ and $\left.\mathrm{GPP}_{\mathrm{MOD17}}\right)$ were more correlative with the eddy covariance derived GPP (GPP ${ }_{\mathrm{OBS}}$ ) in the subtropical forest site (QYZ) than in the tropical forest site (PDF). The adjusted coefficient of determination (Adj. $R^{2}$ ) between the modeled GPPs and GPP ${ }_{\mathrm{OBS}}$ were all above $0.8(p<0.001)$ in the subtropical forest site (QYZ) (Figure 3); however, the four Adj. $R^{2}$ in the tropical forest (PDF) were low and varied in the range 0.15-0.20 (Figure 4). The root-mean-square errors (RMSEs) between the modeled GPPs and GPP ${ }_{\mathrm{OBS}}$ were 1.49 grams of carbon per square meter per day $\left(\mathrm{gC} \cdot \mathrm{m}^{-2} \cdot \mathrm{d}^{-1}\right)\left(\mathrm{GPP}_{\mathrm{NDVI} I 3 \mathrm{~g}}\right), 1.97 \mathrm{gC} \cdot \mathrm{m}^{-2} \cdot \mathrm{d}^{-1}\left(\mathrm{GPP}_{\mathrm{NDVI}}\right), 1.59 \mathrm{gC} \cdot \mathrm{m}^{-2} \cdot \mathrm{d}^{-1}$ $\left(\mathrm{GPP}_{\mathrm{MOD} 15}\right)$ and $0.99 \mathrm{gC} \cdot \mathrm{m}^{-2} \cdot \mathrm{d}^{-1}\left(\mathrm{GPP}_{\mathrm{MOD} 17}\right)$, respectively, in the QYZ site. The corresponding values were $25.37 \mathrm{gC} \cdot \mathrm{m}^{-2} \cdot \mathrm{d}^{-1}, 16.27 \mathrm{gC} \cdot \mathrm{m}^{-2} \cdot \mathrm{d}^{-1}, 41.09 \mathrm{gC} \cdot \mathrm{m}^{-2} \cdot \mathrm{d}^{-1}$ and $4.62 \mathrm{gC} \cdot \mathrm{m}^{-2} \cdot \mathrm{d}^{-1}$ in the PDF site. In the PDF site, the GPP $\mathrm{MOD} 17_{17}$ and GPP $\mathrm{OBS}_{\mathrm{S}}$ values were closer (Figure 4) and GPP $\mathrm{MOD}_{\mathrm{M}}$ had the lowest RMSE with $\mathrm{GPP}_{\mathrm{OBS}}$ less than those of $\mathrm{GPP}_{\mathrm{NDVI} g \mathrm{~g}}$, $\mathrm{GPP}_{\mathrm{NDVII}}, \mathrm{GPP}_{\mathrm{MOD15}}$. However, the seasonal variability of $\mathrm{GPP}_{\mathrm{MOD} 17}$ was not as consistent with $\mathrm{GPP}_{\mathrm{OBS}}$ as those in $\mathrm{GPP}_{\mathrm{NDV} \text { I3g }}$, GPP $\mathrm{NDVI1g}_{\text {, }}$ and GPP ${ }_{\text {MOD15. }}$.

We also conducted a comparison between the modelled and reference GPPs by using the seasonal and annual sum GPP data (Table 2). At the subtropical forest site (QYZ), GPP NDVIsg $_{\text {GPP }}$ NDVIIg $_{\text {, and }}$ $\mathrm{GPP}_{\text {MOD15 }}$ were underestimated by $21 \%, 35 \%$ and $21 \%$ for the whole year, by $8 \%, 23 \%$ and $11 \%$ for the period from May to October, and by $51 \%, 62 \%$ and $43 \%$ for the period from November to April (Table 2). However, at the tropical forest site (PDF), GPP NDVI3g, GPP $_{\text {NDVI1g }}$ and GPP MOD15 $_{15}$ overestimated GPP by $36 \%, 27 \%$ and $-30 \%$ for the whole year, $36 \%, 26 \%$ and $-26 \%$ for May to 
October, $36 \%, 28 \%$ and $-34 \%$ for November to April. These results indicate that the FPAR from GIMMS NDVI3g can capture GPP well in the growing season (May-October) in subtropical forest. MOD17A2 showed elegant performance at the two forest sites with the lower bias of $-2.9 \%$ and $-11.8 \%$ for the whole year, $-6.1 \%$ and $-10.1 \%$ for May to October, and $3.6 \%$ and $-13.6 \%$ for November to April in the QYZ and PDF sites, respectively (Table 2). Even with the closer values, the MOD17A2 has an insignificant correlation with $\operatorname{GPP}_{\mathrm{OBS}}(p=0.815)$ in the PDF site (Figure 4).

Figure 3. The eight-day mean GPP modeled by using the GLOPEM-CEVSA model and the FPARs from GIMMS NDVI3g (GPP NDVI3g $\left._{1},(\mathbf{a}),(\mathbf{b})\right)$, GIMMS NDVI (GPP NDVIIg $\left._{1},(\mathbf{c}),(\mathbf{d})\right)$ and MOD15A2 (GPP $\left.{ }_{\text {MOD15, }},(\mathbf{e}),(\mathbf{f})\right)$ as well as the MODIS GPP products MOD17A2 $\left(\mathrm{GPP}_{\mathrm{MOD17}},(\mathbf{g}),(\mathbf{h})\right)$ compared with the GPP observed on the eddy covariance towers in the QYZ forest site. The seasonal variation ((a), (c), (e), (g)) and the scatter plots ((b), (d), (f), (h)) of the two kinds of GPPs are compared for all the four GPP products $\left(\mathrm{GPP}_{\mathrm{NDVi} g}\right.$, $\mathrm{GPP}_{\mathrm{NDVII}}, \mathrm{GPP}_{\mathrm{MOD} 15}$, and GPP $\left.\mathrm{MOD17}\right)$. Sample number is 138.

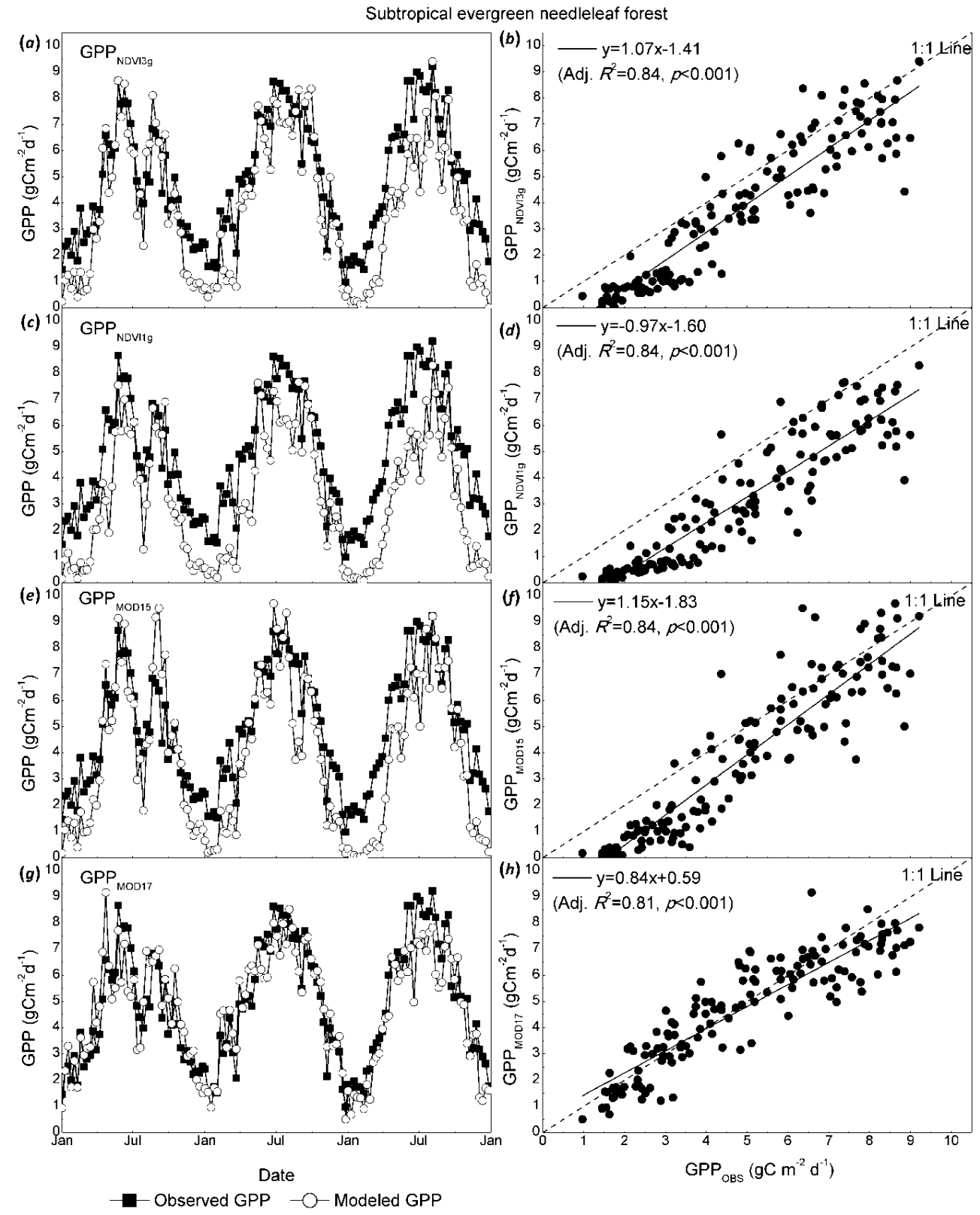


Figure 4. The eight-day mean GPP modeled using the GLOPEM-CEVSA model and the FPAR from GIMMS NDVI3g (GPP NDVI3g $,(\mathbf{a}),(\mathbf{b}))$, GIMMS NDVI (GPP NDVIIg $\left._{1},(\mathbf{c}),(\mathbf{d})\right)$ and MOD15A2 $\left(\mathrm{GPP}_{\mathrm{MOD} 15},(\mathbf{e}),(\mathbf{f})\right)$ as well as the MODIS GPP products MOD17A2 $\left(\mathrm{GPP}_{\mathrm{MOD} 17},(\mathbf{g}),(\mathbf{h})\right)$ compared with the GPP observed on the eddy covariance towers in the PDF tropical peat land forest site. The seasonal variation ((a), (c), (e), (g)) and the scatter plots ((b), (d), (f), (h)) of the two kinds of GPPs are compared for all the four GPP products $\left(\mathrm{GPP}_{\mathrm{NDVI} 3 \mathrm{~g}}, \mathrm{GPP}_{\mathrm{NDVI1}}, \mathrm{GPP}_{\mathrm{MOD} 15}\right.$, and $\left.\mathrm{GPP}_{\mathrm{MOD} 17}\right)$. Sample number is 92.
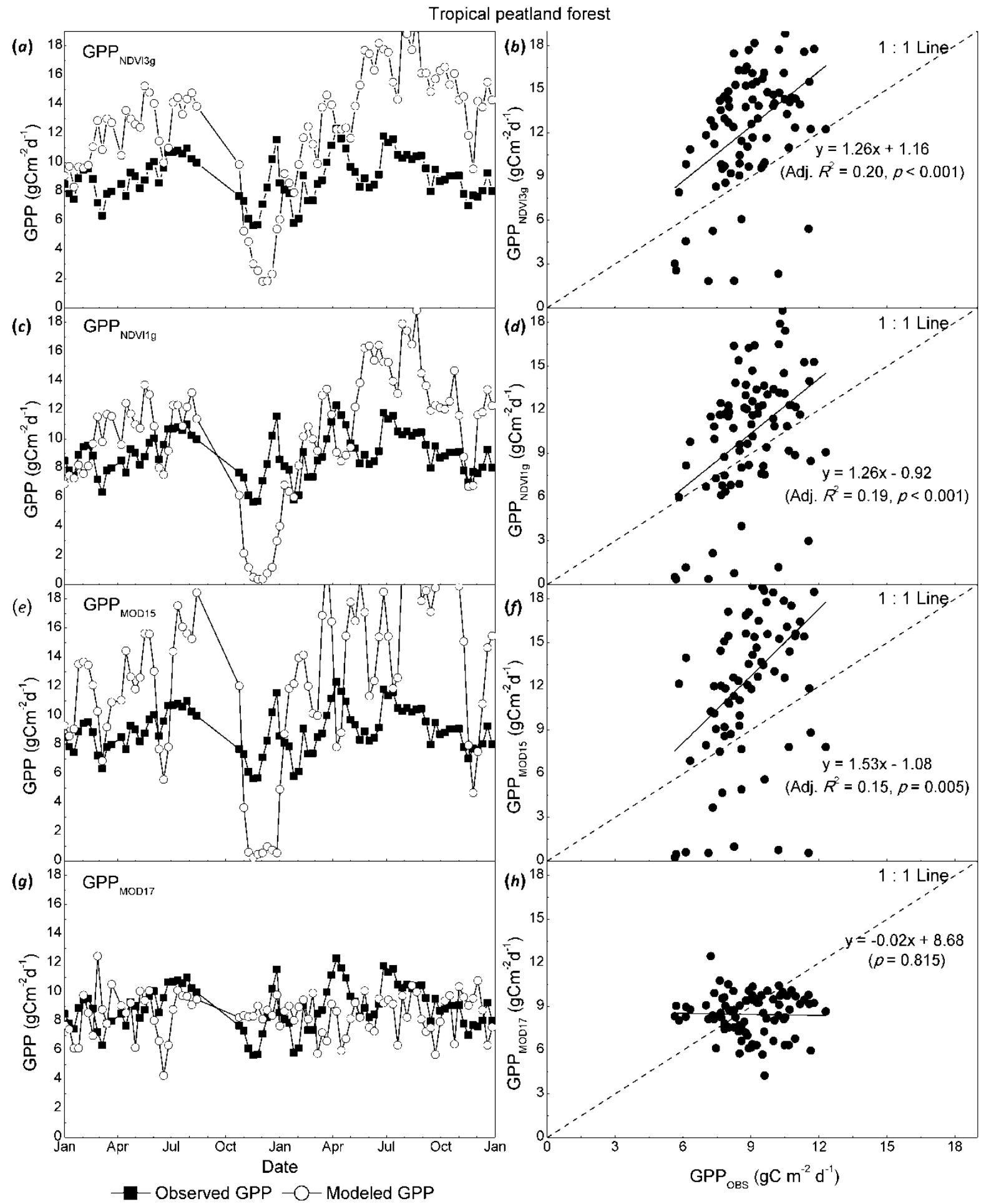
Table 2. The statistics of the modelled and observed GPPs from eddy covariance flux towers at annual and seasonal scales (May-October, November-April) in the evergreen needle-leaf forest at Qianyanzhou (QYZ), Jiangxi province, China and the tropical peat swamp forest at Palangkaraya (PDF), Indonesia. $\mathrm{GPP}_{\mathrm{NDVI} g}$, $\mathrm{GPP}_{\mathrm{NDVI1}}$, and $\mathrm{GPP}_{\mathrm{MOD} 15}$ are the GPP results derived using the GLOPEM-CEVSA model and the GIMMS NDVI3g, GIMMS NDVI and MOD15A2, respectively. GPP ${ }_{\text {MOD17 }}$ and GPP $_{\mathrm{OBS}}$ are GPPs from the MODIS GPP product MOD17A2 and the observed GPPs.

\begin{tabular}{|c|c|c|c|c|c|c|c|c|c|c|}
\hline \multirow{2}{*}{ Period } & \multicolumn{5}{|c|}{ Subtropical Evergreen Needleleaf Forest (QYZ) } & \multicolumn{5}{|c|}{ Tropical Peat Swamp Forest (PDF) } \\
\hline & GPP $_{\text {NDVI3g }}$ & $\mathbf{G P P}_{\text {NDVIIg }}$ & $\mathbf{G P P}_{\mathrm{MOD15}}$ & $\mathbf{G P P}_{\text {MOD17 }}$ & $\mathbf{G P P}_{\mathrm{OBS}}$ & GPP $_{\text {NDVI3g }}$ & GPP $_{\text {NDVIIg }}$ & $\mathbf{G P P}_{\mathrm{MOD15}}$ & $\mathbf{G P P}_{\text {MOD17 }}$ & $\mathbf{G P P}_{\mathrm{OBS}}$ \\
\hline \multicolumn{11}{|c|}{ Whole Year $\left(\mathrm{gC} \cdot \mathrm{m}^{-2} \cdot \mathrm{a}^{-1}\right)$} \\
\hline 2002 & & & & 1803.1 & & 4365.3 & 3350.4 & 2176.6 & 3122.6 & 3246.1 \\
\hline 2003 & 1430.7 & 1080.8 & 1362.6 & 1674.2 & 1610.4 & 4785.2 & 4656.2 & 2487.7 & 3053.4 & 3460.6 \\
\hline 2004 & 1453.7 & 1319.8 & 1606.9 & 1884.6 & 1867.4 & 4786.3 & 4294.8 & 2447.7 & 3166.0 & 3593.8 \\
\hline 2005 & 1319.6 & 1098.2 & 1259.3 & 1653.4 & 1912.0 & 4632.4 & 4023.8 & 2534.2 & 2711.3 & \\
\hline \multicolumn{11}{|c|}{ May-October $\left(\mathrm{gC} \cdot \mathrm{m}^{-2}\right.$ in 6 months $)$} \\
\hline 2002 & & & & 1180.2 & & 2221.6 & 1517.7 & 939.1 & 1575.0 & 1652.3 \\
\hline 2003 & 1091.7 & 862.6 & 1039.4 & 1042.9 & 1068.5 & 2501.3 & 2410.5 & 1333.0 & 1586.6 & 1806.9 \\
\hline 2004 & 1151.0 & 1058.5 & 1211.1 & 1237.4 & 1294.5 & 2451.0 & 2183.2 & 1358.8 & 1698.9 & 1848.3 \\
\hline 2005 & 1130.6 & 935.0 & 1022.2 & 1188.6 & 1340.9 & 2243.7 & 1954.3 & 1366.6 & 1423.3 & \\
\hline \multicolumn{11}{|c|}{ November-April $\left(\mathrm{gC} \cdot \mathrm{m}^{-2}\right.$ in 6 months $)$} \\
\hline 2002 & & & & 623.3 & & 2143.6 & 1832.6 & 1237.5 & 1547.4 & 1593.8 \\
\hline 2003 & 339.0 & 218.1 & 323.2 & 631.4 & 541.9 & 2283.8 & 2245.7 & 1154.7 & 1467.1 & 1653.7 \\
\hline 2004 & 302.6 & 261.3 & 395.8 & 647.2 & 572.9 & 2335.2 & 2111.6 & 1088.9 & 1467.0 & 1745.5 \\
\hline 2005 & 188.9 & 163.2 & 237.1 & 464.9 & 571.1 & 2388.7 & 2069.4 & 1167.7 & 1287.8 & \\
\hline
\end{tabular}

\subsection{GPP Assessments on Annual Scale}

More annual GPP data estimated from the observations on the eddy towers were collected from the peer-reviewed literature (see Table 1). A comparison of results is shown in Figure 5. GPP $\mathrm{MOD} 15_{\text {had }}$ the

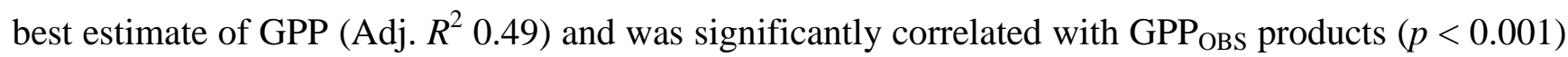



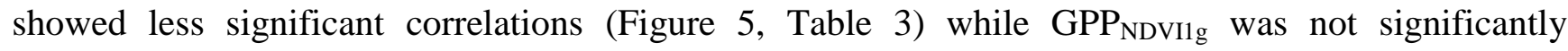
correlated with $\mathrm{GPP}_{\mathrm{OBS}}(p=0.74)$.

The GPP validation data were diverse, e.g., PDF-DB is a site where the forest was burnt in 1997 and 2002. Also, the fetch of the eddy tower with 4-m height was too small (around 250-1000 $\mathrm{m}$ in different directions) [73], such that the GPP simulation at 8-km resolution was unable to capture the fire effects. After excluding the PDF-DB site, the Adj. $R^{2}$ increased to 0.85 and 0.51 , respectively, for the GPP MOD15 $_{\text {and GPP }}$ MOD17 estimates (Table 3).

We excluded more abnormal observation points progressively to achieve a group of best fits (shown as the solid lines in Figure 5) at which the Adj. $R^{2}$ reached a maximum value (best-fitting hereafter). The adjusted $R^{2}$ for $\mathrm{GPP}_{\text {NDVI3g }}$ was always higher than that for GPP $\mathrm{NDVIIg}_{\text {in }}$ in step, which suggested that GIMMS NDVI3g has higher quality than its old version (GIMMS NDVI) in GPP monitoring. The adjusted $R^{2}$ for GPP $\mathrm{NDVI}_{\mathrm{g} g}$ and $\mathrm{GPP}_{\text {NDVIIg }}$ underwent a dramatic improvement to 0.82 and 0.73 after the best-fitting. The $\mathrm{GPP}_{\text {NDVI3g }}$ overestimated the regression slope (1.05 in Table 3 ) by 
$5 \%$ and the $\mathrm{GPP}_{\mathrm{NDVIIg}}$ underestimated it by $43 \%$. The $\mathrm{GPP}_{\mathrm{MOD} 15}$ reached the best-fit after removing only one site (PDF-DB) with the Adj. $R^{2}$ 0.85; while the GPP ${ }_{\mathrm{MOD} 17}$ reached the best-fit after removing two sites (PDF-DB and MKL) with the Adj. $R^{2} 0.67$. The GIMMS NDVI3g had a better estimate of GPP $($ slope $=1.05)$ relative to the MOD15 (slope $=0.87)$ and MOD17 (slope $=0.45)$ based on the final best-fit sites. These results indicate GIMMS NDVI3g has a reasonably good capability to simulate GPP. GPP ${ }_{\text {MOD15 }}$ had the highest accuracy with a higher coefficient of determination (Adj. $R^{2}$ ) and significance $(p)$ in all three situations (all data, excluding PDF-DB, and best fitting).

\subsection{Spatial and Temporal Comparison among Four GPP Results}

A linear regression analysis was applied to investigate the consistency between $\mathrm{GPP}_{\mathrm{NDVI} g}$ and the other three results $\left(\mathrm{GPP}_{\mathrm{MOD15}}, \mathrm{GPP}_{\mathrm{NDVI1}}, \mathrm{GPP}_{\mathrm{MOD} 17}\right)$ and the scatter plots are shown in Figure 6 . The results indicated that the $\mathrm{GPP}_{\mathrm{NDVI} g}$ have significant linear correlations $(p<0.0001)$ with the other three results. Due to the higher data range of the original GIMMS NDVI3g data, GPP NDVI3g

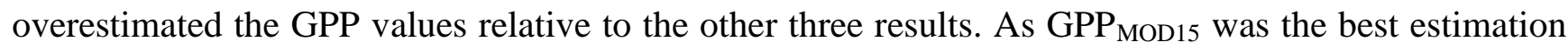
stated in Section 3.2(2), we used it as the baseline and adjusted the $\mathrm{GPP}_{\mathrm{NDVI} g}$ by using the linear regression coefficient. The adjusted $\mathrm{GPP}_{\mathrm{NDVI} g}$ was used for the following analysis and comparisons.

Figure 5. GPP data published in peer-reviewed literature (Table 1) compared with GPP

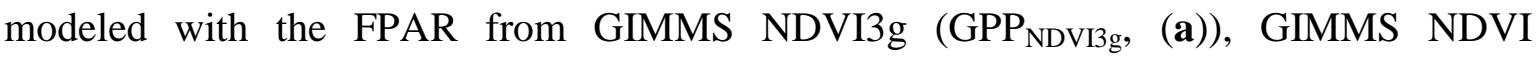
$\left(\mathrm{GPP}_{\text {NDVIIg }},(\mathbf{b})\right)$, MOD15A2 (GPP $\left.\mathrm{MOD15}_{15},(\mathbf{c})\right)$ through GLOPEM-CEVSA model, and the

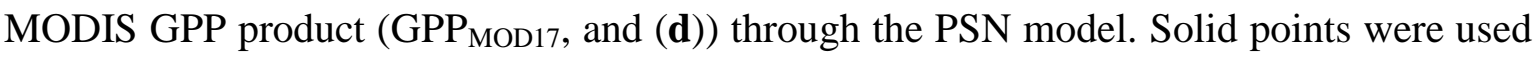
in the linear regressions; open points were excluded as exceptions. The relationships between the modeled ( $\left.\mathrm{GPP}_{\mathrm{MOD}}\right)$ and the observed GPP (GPP $\left.\mathrm{GBS}_{\mathrm{O} S}\right)$ are shown in Table 3 for three levels: all data, data excluding the PDF-DB site, and best fit data (solid points). The sample numbers are detailed in Table 3.

(a)

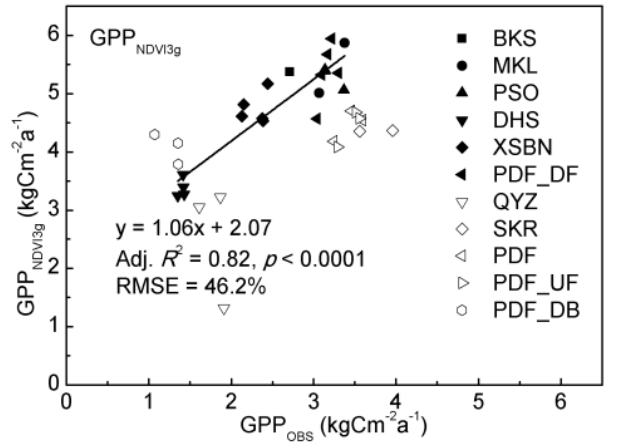

(c)

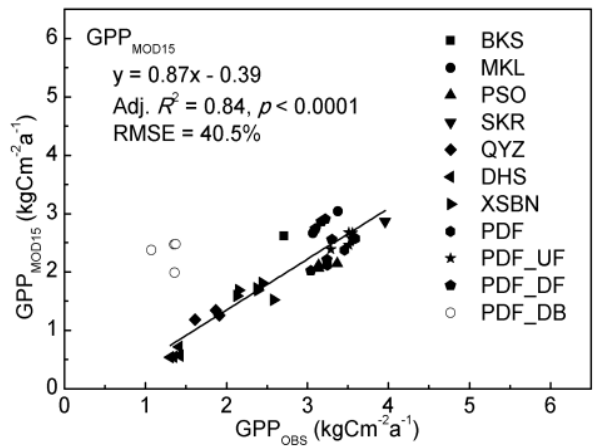

(b)

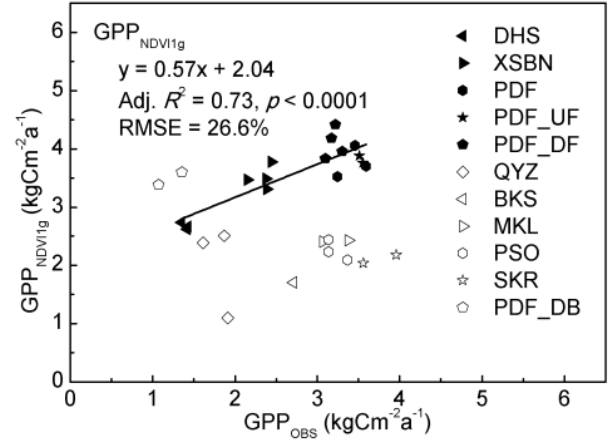

(d)

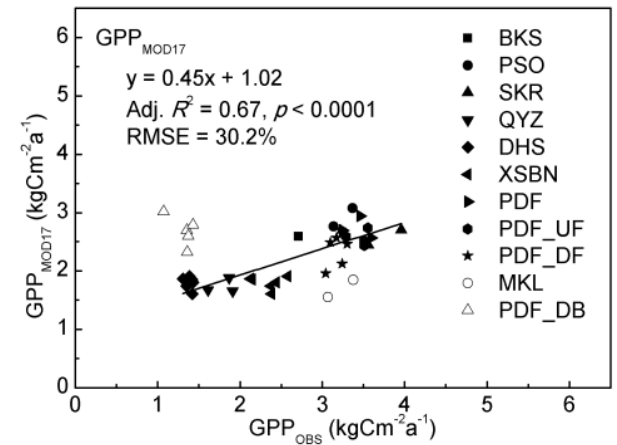


Table 3. Comparison of linear regression results of modeled (GPPMOD) and observed GPP (GPPOBS) with the formula: $G P P_{M O D}=G P P_{O B S} \times$ slope + Intercept. GPP was modelled by GLOPEM-CEVSA with FPAR from GIMMS NDVI3g, GIMMS NDVI and MODIS product (MOD15A2) respectively. MOD17A2 is the GPP product of MODIS and was calculated by the MOD17 algorithm applying the FPAR from MOD15A2. The results are given with the value and error of intercept and slope, the statistics of adjusted coefficient of determination (Adj. $R^{2}$ ) and significance level $(p)$, and the relative root-mean-square error (RMSE, \%). PDF-DB is for data acquired at the swamp forest (DB) site of PDF disturbed by burning.

\begin{tabular}{|c|c|c|c|c|c|c|c|c|}
\hline \multirow{2}{*}{ Modeled GPP } & \multicolumn{2}{|c|}{ Intercept } & \multicolumn{2}{|c|}{ Slope } & \multicolumn{2}{|c|}{ Statistics } & \multirow{2}{*}{$\begin{array}{c}\text { RMSE } \\
(\%)\end{array}$} & \multirow{2}{*}{$\begin{array}{c}\text { Sample } \\
\text { Number }\end{array}$} \\
\hline & Value & Error & Value & Error & Adj. $R^{2}$ & $p$ & & \\
\hline \multicolumn{9}{|l|}{ All data } \\
\hline $\mathrm{GPP}_{\text {NDVI3g }}$ & 3.10 & 0.33 & 0.53 & 0.12 & 0.35 & 0.00 & 72.8 & 38 \\
\hline $\mathrm{GPP}_{\text {NDVIIg }}$ & 3.10 & 0.52 & -0.06 & 0.18 & -0.03 & 0.74 & 37.9 & 33 \\
\hline $\mathrm{GPP}_{\mathrm{MOD} 15}$ & 0.53 & 0.25 & 0.57 & 0.09 & 0.49 & 0.00 & 32.6 & 43 \\
\hline $\mathrm{GPP}_{\mathrm{MOD} 17}$ & 1.76 & 0.22 & 0.23 & 0.08 & 0.16 & 0.00 & 34.1 & 43 \\
\hline \multicolumn{9}{|c|}{ Exclude PDF-DB } \\
\hline $\mathrm{GPP}_{\text {NDVI3g }}$ & 2.84 & 0.41 & 0.61 & 0.14 & 0.35 & 0.00 & 66.2 & 35 \\
\hline $\mathrm{GPP}_{\text {NDVI1g }}$ & 2.79 & 0.63 & 0.04 & 0.21 & -0.03 & 0.87 & 32.1 & 31 \\
\hline $\mathrm{GPP}_{\mathrm{MOD} 15}$ & -0.42 & 0.17 & 0.87 & 0.06 & 0.85 & 0.00 & 29.8 & 39 \\
\hline $\mathrm{GPP}_{\mathrm{MOD} 17}$ & 1.03 & 0.22 & 0.45 & 0.07 & 0.51 & 0.00 & 28.0 & 38 \\
\hline \multicolumn{9}{|l|}{ Best-Fitting } \\
\hline $\mathrm{GPP}_{\text {NDVI3g }}$ & 2.07 & 0.30 & 1.06 & 0.11 & 0.82 & 0.00 & 46.2 & 19 \\
\hline $\mathrm{GPP}_{\text {NDVI1g }}$ & 2.04 & 0.25 & 0.57 & 0.09 & 0.73 & 0.00 & 26.6 & 14 \\
\hline $\mathrm{GPP}_{\mathrm{MOD} 15}$ & -0.42 & 0.17 & 0.87 & 0.06 & 0.85 & 0.00 & 29.8 & 39 \\
\hline $\mathrm{GPP}_{\mathrm{MOD} 17}$ & 1.02 & 0.15 & 0.45 & 0.05 & 0.67 & 0.00 & 30.2 & 33 \\
\hline
\end{tabular}

Figure 6. Scatter plots of annual GPP between the GIMMS NDVI3g based GPP

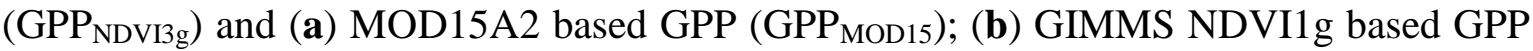
$\left(\mathrm{GPP}_{\mathrm{NDVII}}\right)$; (c) the MODIS GPP product MOD17A2 (GPP $\left.\mathrm{GOD}_{17}\right)$.
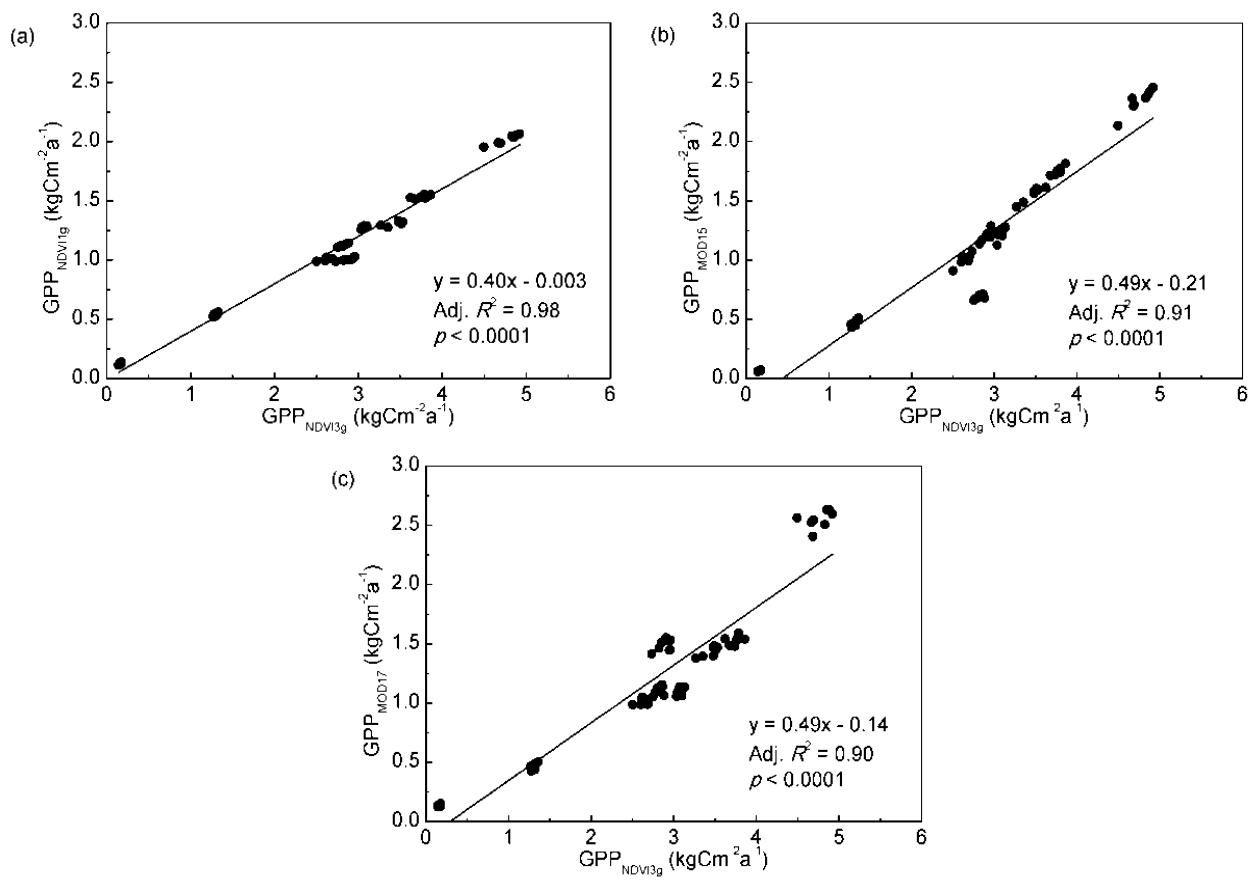
Due to the data availability, GPP $\mathrm{NDVI3g}, \mathrm{GPP}_{\mathrm{NDVI1}}$, GPP $\mathrm{MOD15}_{15}$, and $\mathrm{GPP}_{\mathrm{MOD} 17}$ had different date ranges for Southeast Asia, but all of them had an overlap period from 2000-2006. We calculated the multi-year average of GPPs in 2000-2006 to compare their spatial patterns. Figure 7 shows that all the four GPP results had similar spatial patterns. The Tibetan Plateau had the lowest GPP values, while the highest GPP values occurred in the tropical forest areas in Malaysia and Indonesia. In India, however, the four datasets had inconsistent patterns, and especially GPP $_{\text {MOD17 }}$ had a lower estimate than the other three (Figure 7). This discrepancy could be associated with the lower estimate of MOD17 model in the crop GPP simulation (Table 4), as there is a large area of cropland (mainly double paddy rice cropping) in India.

Figure 7. Spatial patterns of the annual average GPP in 2000-2006 in Southeast Asia: (a) $\mathrm{GPP}_{\mathrm{NDVI} g \mathrm{~g}}$; (b) GPP $\mathrm{GDVI1g}$; (c) $\mathrm{GPP}_{\mathrm{MOD} 15}$; and (d) $\mathrm{GPP}_{\mathrm{MOD} 17}$.


Statistics of the average GPPs of different vegetation types are shown in Table 4. The average forest GPP in Southeast Asia ranged from $1.79 \pm 0.03$ kilogram of carbon per square meter per year $\left(\mathrm{kgC} \cdot \mathrm{m}^{-2} \cdot \mathrm{a}^{-1}\right)\left(\mathrm{GPP}_{\mathrm{NDVII}}\right)$ to $2.20 \pm 0.06 \mathrm{kgC} \cdot \mathrm{m}^{-2} \cdot \mathrm{a}^{-1}\left(\mathrm{GPP}_{\mathrm{MOD} 17}\right)$, while GPP $\mathrm{NDVI3g}, \mathrm{GPP}_{\mathrm{MOD} 15}$ had GPP estimates in the order of $2.12 \pm 0.06 \mathrm{kgC} \cdot \mathrm{m}^{-2} \cdot \mathrm{a}^{-1}$ and $2.08 \pm 0.09 \mathrm{kgC} \cdot \mathrm{m}^{-2} \cdot \mathrm{a}^{-1}$. All of the four products had highest GPP values in evergreen broadleaf forest $\left(2.02-2.57 \mathrm{kgC} \cdot \mathrm{m}^{-2} \cdot \mathrm{a}^{-1}\right)$ while the lowest GPP values were in evergreen needle-leaf forest $\left(0.84-1.14 \mathrm{kgC} \cdot \mathrm{m}^{-2} \cdot \mathrm{a}^{-1}\right)$.

The forest ecosystem had the largest carbon uptake with total GPP of 8.8 petagram of carbon per year (Pg. $\cdot \mathrm{a}^{-1}=10^{15}$ gram carbon per year). This accounted for $43 \%$ of the total vegetation carbon uptake although its area accounts for $30 \%$ of the study area. Croplands accounted for $32 \%$ of the carbon and $31 \%$ of the area, and grassland $21 \%$ of the carbon uptake over $24 \%$ of the area. Of the forest types, evergreen broadleaf forest had the highest GPP of $6.6 \mathrm{Pg} \cdot \mathrm{C} \cdot \mathrm{a}^{-1}$ over $69 \%$ of the total forest area, followed by mixed forest with $1.5 \mathrm{Pg} \cdot \mathrm{C} \cdot \mathrm{a}^{-1}$ over $29.1 \%$ of the area (Table 4 ). In total, 
all the vegetation in our studied Southeast Asia had a total carbon uptake of $20 \mathrm{Pg} \cdot \mathrm{C} \cdot \mathrm{a}^{-1}$. Beer et al. [3] reported an observation-based global GPP estimate of about $123 \pm 8 \mathrm{Pg} \cdot \mathrm{C} \cdot \mathrm{a}^{-1}$. Therefore, from our estimates, Southeast Asia contributes about 14\% 16\% of the global carbon flux.

Table 4. The modelled GPP for the main vegetation types in Southeast Asia, from GIMMS NDVI3g (GPP NDVI3g $)$, GIMMS NDVI (GPP NDVIIg $)$ and MOD15A2 (GPP MOD15 $)$ based on the GLOPEM-CEVSA model, and the MODIS GPP product (MOD17A2) based on the PSN model. Spatial statistics were calculated using GPP and land cover data shown in Figures 2 and 7.

\begin{tabular}{|c|c|c|c|c|c|c|}
\hline $\begin{array}{c}\text { Vegetation } \\
\text { Type } \\
\end{array}$ & $\begin{array}{c}\mathbf{G P P}_{\text {NDVI3g }} \\
\left(\mathrm{kgC} \cdot \mathbf{m}^{-2} \cdot \mathbf{a}^{-1}\right) \\
\end{array}$ & $\begin{array}{c}\mathbf{G P P}_{\mathrm{NDVII}} \\
\left(\mathrm{kgC} \cdot \mathbf{m}^{-2} \cdot \mathbf{a}^{-1}\right) \\
\end{array}$ & $\begin{array}{c}\mathbf{G P P}_{\mathrm{MOD15}} \\
\left(\mathrm{kgC} \cdot \mathbf{m}^{-2} \cdot \mathbf{a}^{-1}\right) \\
\end{array}$ & $\begin{array}{c}\mathbf{G P P}_{\mathrm{MOD17}} \\
\left(\mathbf{k g C} \cdot \mathbf{m}^{-2} \cdot \mathbf{a}^{-1}\right) \\
\end{array}$ & $\begin{array}{c}\text { Vegetation } \\
\text { Area \% } \\
\end{array}$ & $\begin{array}{c}\text { Total GPP } \\
\quad\left(\mathbf{P g} \cdot \mathbf{C} \cdot \mathbf{a}^{-1}\right) \\
\end{array}$ \\
\hline Forest & $2.12 \pm 0.06$ & $1.79 \pm 0.03$ & $2.08 \pm 0.09$ & $2.20 \pm 0.06$ & 29.8 & 8.78 \\
\hline$E N F$ & $1.14 \pm 0.04$ & $0.84 \pm 0.03$ & $0.91 \pm 0.06$ & $1.03 \pm 0.05$ & $4.2 *$ & 0.20 \\
\hline$D N F$ & $1.41 \pm 0.04$ & $1.01 \pm 0.01$ & $1.18 \pm 0.07$ & $1.49 \pm 0.05$ & $0.1 *$ & 0.00 \\
\hline$M F$ & $1.69 \pm 0.05$ & $1.31 \pm 0.02$ & $1.55 \pm 0.06$ & $1.43 \pm 0.04$ & $21.9 *$ & 1.53 \\
\hline$E B F$ & $2.33 \pm 0.07$ & $2.02 \pm 0.04$ & $2.35 \pm 0.10$ & $2.57 \pm 0.07$ & $68.6 *$ & 6.63 \\
\hline$D B F$ & $1.84 \pm 0.04$ & $1.53 \pm 0.01$ & $1.73 \pm 0.06$ & $1.53 \pm 0.04$ & $5.3 *$ & 0.41 \\
\hline Crop & $1.51 \pm 0.02$ & $1.28 \pm 0.01$ & $1.21 \pm 0.04$ & $1.10 \pm 0.03$ & 30.8 & 6.46 \\
\hline Grass & $1.28 \pm 0.03$ & $1.00 \pm 0.01$ & $1.00 \pm 0.04$ & $1.01 \pm 0.03$ & 23.8 & 4.26 \\
\hline Shrub & $0.64 \pm 0.02$ & $0.54 \pm 0.02$ & $0.46 \pm 0.03$ & $0.46 \pm 0.03$ & 7.4 & 0.66 \\
\hline Barren & $0.08 \pm 0.01$ & $0.12 \pm 0.01$ & $0.06 \pm 0.00$ & $0.13 \pm 0.01$ & 8.2 & 0.09 \\
\hline Total & $1.45 \pm 0.03$ & $1.21 \pm 0.02$ & $1.27 \pm 0.05$ & $1.28 \pm 0.04$ & 100 & 20.24 \\
\hline
\end{tabular}

Forest types: ENF: evergreen needle-leaf forest; MF: mixed forest; EBF: evergreen broad-leaf forest; DBF: deciduous broad-leaf forest. * percentage area of forest subtypes in the whole forest area.

\section{Discussion}

\subsection{Uncertainty in GPP Modelling}

GLOPEM-CEVSA based GPP estimates were calculated with three different FPAR datasets

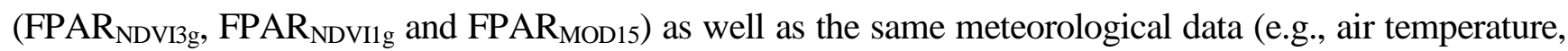
dew point, and wind speed). Validations and comparisons showed that GIMMS NDVI3g is comparable in capabilities to MODIS data for spatial and temporal modelling of GPP.

While using the same MODIS FPAR data, GLOPEM-CEVSA based GPP ${ }_{\text {MOD15 }}$ showed better accuracy than that of GPP MOD17 $_{1}$ based on the MODIS algorithm, indicating better potential for application of the GLOPEM-CEVSA model for the study region. An important factor contributing to uncertainty in GPP $_{\text {NDVI3g }}$ could be that of the GIMMS NDVI3g data. For example, Fensholt et al. [81] found that correlations between GIMMS NDVI3g and MODIS NDVI datasets are highly significant for areas with a distinct phenological cycle (e.g., temperate forest), while the discrepancies between them are large in equatorial areas (e.g., tropical evergreen forest). The temporal and spatial resolutions could also affect the quality of satellite-based FPAR and GPP estimates. GIMMS NDVI3g and MODIS have temporal resolutions of half-month and eight-days, respectively, while their spatial resolutions are 8-km and 1-km, respectively. Consequently, GIMMS NDVI3g most likely neglects some fragmentary landscapes. Since the landscape of Southeast Asia has been seriously fragmented due to its mountainous terrain and rapid deforestation over the course of the study period [82], MODIS likely performs better in areas of high disturbance and/or land cover change. However, we aggregated 
the MODIS FPAR to match the GIMMS NDVI3g data, which diminished the advantages of MODIS in spatial resolution. Despite a relatively coarse spatial resolution, GIMMS NDVI3g is the longest continuous temporal record of vegetation dynamic and as such represents a critical data source for discovering the responses of vegetation to climate change over the long time span from the 1980s to the present.

The land cover information was another main source of uncertainty that influenced GPP estimates. Retrieved GPP would be substantially affected if land cover were wrongly classified, e.g., misclassification of subtropical evergreen forest as woody savanna would lead to a substantial bias due to differences in parameterization. Therefore, accurate land cover classification is critical for the simulation of GPP at the regional scale. Other factors, e.g., canopy structure, could greatly influence upstream inputs (e.g., LAI retrieval) and finally affect the GPP estimates [25,83].

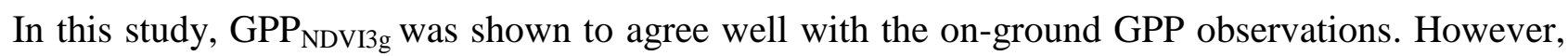
$\mathrm{GPP}_{\text {NDVI3g }}$ overestimated GPP in absolute values (Figure 6). This discrepancy could be related to the higher data range in the original GIMMS NDVI3g data, which was ultimately transferred to FPAR $_{\text {NDVI3g }}$ due to the application of a linear algorithm (Equations (9)-(11)). The newly released GIMMS FPAR3g data could solve this problem, as the GIMMS NDVI3g and MODIS FPAR (MOD15A2) products for the overlapping period 2000-2009 were harmonized using a neural network algorithm [84]. However, in our research we simulated GPP using the independent GIMMS NDVI3g data, in an effort to evaluate the potential of this dataset for GPP modelling.

\subsection{Uncertainty in FPAR}

FPAR is one of the main uncertainty sources that linearly influence GPP $[16,50,85]$. The accuracy of satellite-based FPAR could be affected by many factors, e.g., land cover data, surface reflectance or NDVI data, and the algorithm [86]. According to Los et al. [55], satellite-derived biophysical parameters are less sensitive to errors in the land cover classification than land cover-derived parameters. This is because they have only second order dependency on land cover type and the land cover type accounts for at most $10 \%$ of the variation in FPAR. We estimated $\mathrm{NDVI}_{\max }$ and $\mathrm{NDVI}_{\min }$ using the NDVIs located at the $98 \%$ and $2 \%$ of the NDVI frequency distribution for all vegetated area without considering various land cover types.

While using the same GLOPEM-CEVSA model settings, GPP ${ }_{\text {MOD15 }}$ was more accurate than $\mathrm{GPP}_{\text {MOD17 }}$ based on PSN, which indicated a high potential of the GLOPEM-CEVSA model for this study region. However, the higher accuracy in simulating GPPs implied that the adaptive SG filtered FPAR data could have a better performance than the FPAR data based on the linear interpolation approach using in the MODIS algorithm. In order to both fill unreliable and missing FPAR values and keep reliable values, the MODIS model applied linear interpolation of the nearest reliable values to recover temporal time series of FPAR [25]. This method probably removed some intrinsic seasonal variability and resulted in a lower correlation coefficient despite a lower bias. Conversely, we used the MODIS FPAR data filtered by the adaptive SG method in the TIMESAT software package [62,87] as input into the GLOPEM-CEVSA model, which enabled us to capture more of the seasonal variability $[88,89]$. We did not use the data quality information in the MODIS FPAR product (MOD15A2) as previous studies showed that the quality flag layer does not provide sufficient 
information regarding data quality [89], while the quality control information was considered in the MODIS algorithm [25].

\section{Conclusions}

Tropical forests play a very important role in global carbon cycling and climate change, especially when undergoing tropical forest degradation and deforestation induced by a growing human population and forest resource requirements [90]. Satellite-based estimates of gross primary production (GPP) are a wall-to-wall modelling of vegetation dynamics dependent on NDVI data. As the longest time series of remote sensing data, GIMMS NDVI3g is a critical data source to track vegetation activity and changes for the past 30 years. Based on the GLOPEM-CEVSA model, three different

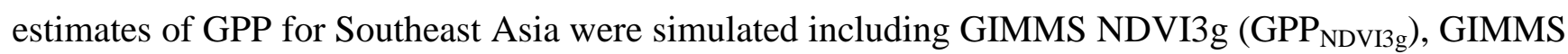

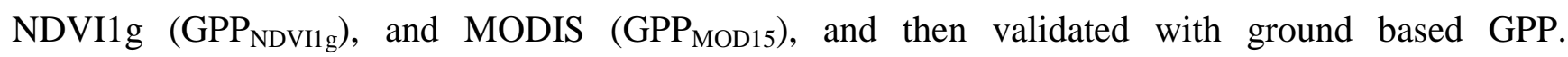
In addition, comparisons were made among the three GPPs as well as against the MODIS GPP product $\left(\mathrm{GPP}_{\mathrm{MOD} 17}\right)$. By validation of the intra-annual variability of GPP at the QYZ and PDF flux tower sites and site-year level at an additional eight sites, we found that $\mathrm{GPP}_{\mathrm{NDVI} g}$ has a higher accuracy relative to $\mathrm{GPP}_{\mathrm{NDVII}}$ and was comparable with the $\mathrm{GPP}_{\mathrm{MOD} 15}$. However, further validation in other ecosystem types are needed in the future, especially when these products are used for non-forest ecosystems such as grassland and cropland. An independent validation of the intermediate variable FPAR would also help to reduce uncertainty and improve future GPP estimates.

Ultimately, our results test and validate GIMMS NDVI3g data for long-term quantification and monitoring of vegetation productivity, specifically for our study region of Southeast Asia, which notably includes tropical forests under increasing deforestation pressure. Our findings suggest that these data have the potential to critically advance the current understanding of ecosystem responses to global climate change and human activities at the regional and global scale

\section{Acknowledgments}

This work was supported by grants from the National Key Basic Research and Development Program (2009CB421105) and the National Natural Science Foundation of China (No. 31270520, 40975045). S. Running was supported by NASA Earth Observing System MODIS Grant (No. NNX08AG87A). The radiation data were obtained from the NASA Langley Research Center Atmospheric Sciences Data Center NASA/GEWEX SRB Project.

\section{Author Contributions}

Junbang Wang, Jingwei Dong, Jiyuan Liu, Mei Huang, Guicai Li, Steven W. Running, W. Kolby Smith and Xiangming Xiao designed the research. Junbang Wang and Jingwei Dong mainly analyzed data and prepared the manuscript and figures. Warwick Harris reviewed and polished the manuscript. Nobuko Saigusa, Hiroaki Kondo, Yunfen Liu, Takashi Hirano provided data. All the authors contributed to the data analysis and paper writing and shared equally in the editing of the manuscript. 


\section{Conflicts of Interest}

The authors declare no conflict of interest.

\section{References}

1. Xiao, X.; Hollinger, D.; Aber, J.; Goltz, M.; Davidson, E.A.; Zhang, Q.; Moore, B. Satellite-based modeling of gross primary production in an evergreen needleleaf forest. Remote Sens. Environ. 2004, 89, 519-534.

2. Gao, Q.; Li, Y.; Wan, Y.; Qin, X.; Wang, J.; Liu, Y. Dynamics of alpine grassland NPP and its response to climate change in Northern Tibet. Clim. Chang. 2009, 97, 515-528.

3. Beer, C.; Reichstein, M.; Tomelleri, E.; Ciais, P.; Jung, M.; Carvalhais, N.; Rodenbeck, C.; Arain, M.A.; Baldocchi, D.; Bonan, G.B.; et al. Terrestrial gross carbon dioxide uptake: Global distribution and covariation with climate. Science 2010, 329, 834-838.

4. Falge, E.; Baldocchi, D.; Tenhunen, J.; Aubinet, M.; Bakwin, P.; Berbigier, P.; Bernhofer, C.; Burba, G.; Clement, R.; Davis, K.J.; et al. Seasonality of ecosystem respiration and gross primary production as derived from FLUXNET measurements. Agric. For. Meteorol. 2002, 113, 53-74.

5. Luo, T.; Li, W.; Zhu, H. Estimated biomass and productivity of natural vegetation on the Tibetan Plateau. Ecol. Appl. 2002, 12, 980-997.

6. Piao, S.; Fang, J.; He, J. Variations in vegetation net primary production in the Qinghai-Xizang Plateau, China, from 1982 to 1999. Clim. Chang. 2006, 74, 253-267.

7. Baldocchi, D.D. Assessing the eddy covariance technique for evaluating carbon dioxide exchange rates of ecosystems: Past, present and future. Glob. Chang. Biol. 2003, 9, 479-492.

8. Running, S.W.; Baldocchi, D.; Turner, D.; Gower, S.; Bakwin, P.; Hibbard, K. A global terrestrial monitoring network integrating tower fluxes, flask sampling, ecosystem modeling and EOS satellite data. Remote Sens. Environ. 1999, 70, 108-127.

9. Wang, J.; Liu, J.; Cao, M.; Liu, Y.; Yu, G.; Li, G.; Qi, S.; Li, K. Modelling carbon fluxes of different forests by coupling a remote-sensing model with an ecosystem process model. Int. J. Remote Sens. 2011, 32, 6539-6567.

10. Cao, M.; Yu, G.; Liu, J.; Li, K. Multi-scale observation and cross-scale mechanistic modeling on terrestrial ecosystem carbon cycle. Sci. China Ser. D 2005, 48, 17-32.

11. Liu, J.; Chen, J.; Cihlar, J.; Park, W. A process-based boreal ecosystem productivity simulator using remote sensing inputs. Remote Sens. Environ. 1997, 62, 158-175.

12. Churkina, G.; Tenhunen, J.; Thornton, P.; Falge, E.M.; Elbers, J.A.; Erhard, M.; Grunwald, T.; Kowalski, A.S.; Rannik, U.; Sprinz, D. Analyzing the ecosystem carbon dynamics of four European coniferous forests using a biogeochemistry model. Ecosystems 2003, 6, 168-184.

13. Law, B.E.; Waring, R.H.; Anthoni, P.M.; Aber, J.D. Measurements of gross and net ecosystem productivity and water vapour exchange of a Pinus ponderosa ecosystem, and an evaluation of two generalized models. Glob. Chang. Biol. 2000, 6, 155-168.

14. Churkina, G.; Running, S.W. Contrasting climatic controls on the estimated productivity of global terrestrial biomes. Ecosystems 1998, 1, 206-215. 
15. Turner, D.P.; Urbanski, S.; Bremer, D.; Wofsy, S.C.; Meyers, T.; Gower, S.T.; Gregory, M. A cross-biome comparison of daily light use efficiency for gross primary production. Glob. Chang. Biol. 2003, 9, 383-395.

16. Turner, D.P.; Ritts, W.D.; Cohen, W.B.; Gower, S.T.; Zhao, M.; Running, S.W.; Wofsy, S.C.; Urbanski, S.; Dunn, A.L.; Munger, J.W. Scaling Gross Primary Production (GPP) over boreal and deciduous forest landscapes in support of MODIS GPP product validation. Remote Sens. Environ. 2003, 88, 256-270.

17. Xiao, X.; Zhang, Q.; Braswell, B.; Urbanski, S.; Boles, S.; Wofsy, S.; Moore, B., III; Ojima, D. Modeling gross primary production of temperate deciduous broadleaf forest using satellite images and climate data. Remote Sens. Environ. 2004, 91, 256-270.

18. Xiao, X.M.; Zhang, Q.Y.; Hollinger, D.; Aber, J.; Moore, B. Modeling gross primary production of an evergreen needleleaf forest using modis and climate data. Ecol. Appl. 2005, 15, 954-969.

19. Behrenfeld, M.J.; Randerson, J.T.; McClain, C.R.; Feldman, G.C.; Los, S.O.; Tucker, C.J.; Falkowski, P.G.; Field, C.B.; Frouin, R.; Esaias, W.E. Biospheric primary production during an ENSO transition. Science 2001, 291, 2594-2597.

20. Field, C.B.; Randerson, J.T.; Malmstrom, C.M. Global net primary production: Combining ecology and remote sensing. Remote Sens. Environ. 1995, 51, 74-88.

21. Potter, C.S.; Randerson, J.T.; Field, C.B.; Matson, P.A.; Vitousek, P.M.; Mooney, H.A.; Klooster, S.A. Terrestrial ecosystem production: A process model based on global satellite and surface data. Glob. Biogeochem. Cycle 1993, 7, 811-841.

22. Prince, S.D.; Goward, S.N. Global primary production: A remote sensing approach. J. Biogeog. 1995, 2, 815-835.

23. Ruimy, A.; Saugier, B.; Dedieu, G. Methodology for the estimation of terrestrial net primary production from remotely sensed data. J. Geophys. Res.-Atmos. 1994, 99, 5263-5283.

24. Alton, P.; Bodin, P. A comparative study of a multilayer and a productivity (light-use) efficiency land-surface model over different temporal scales. Agric. For. Meteorol. 2010, 150, 182-195.

25. Zhao, M.S.; Heinsch, F.A.; Nemani, R.R.; Running, S.W. Improvements of the MODIS terrestrial gross and net primary production global data set. Remote Sens. Environ. 2005, 95, 164-176.

26. Yuan, W.; Liu, S.; Zhou, G.; Zhou, G.; Tieszen, L.L.; Baldocchi, D.; Bernhofer, C.; Gholz, H.; Goldstein, A.H.; Goulden, M.L.; et al. Deriving a light use efficiency model from eddy covariance flux data for predicting daily gross primary production across biomes. Agr. For. Meteorol. 2007, 143, 189-207.

27. Wu, C.; Munger, J.W.; Niu, Z.; Kuang, D. Comparison of multiple models for estimating gross primary production using MODIS and eddy covariance data in Harvard Forest. Remote Sens. Environ. 2010, 114, 2925-2939.

28. Ryu, Y.; Baldocchi, D.D.; Kobayashi, H.; Ingen, C.; Li, J.; Black, T.A.; Beringer, J.; Gorsel, E.; Knohl, A.; Law, B.E. Integration of MODIS land and atmosphere products with a coupled-process model to estimate gross primary productivity and evapotranspiration from $1 \mathrm{~km}$ to global scales. Glob. Biogeochem. Cycle 2011, 25, doi:10.1029/2011GB004053.

29. Wu, C.; Chen, J.M.; Desai, A.R.; Hollinger, D.Y.; Arain, M.A.; Margolis, H.A.; Gough, C.M.; Staebler, R.M. Remote sensing of canopy light use efficiency in temperate and boreal forests of North America using MODIS imagery. Remote Sens. Environ. 2012, 118, 60-72. 
30. Cramer, W.; Kicklighter, D.; Bondeau, A.; Iii, B.M.; Churkina, G.; Nemry, B.; Ruimy, A.; Schloss, A. Comparing global models of terrestrial net primary productivity (NPP): Overview and key results. Glob. Chang. Biol. 1999, 5, 1-15.

31. Zhao, G.; Wang, J.; Fan, W.; Ying, T. Vegetation net primary productivity in Northeast China in 2000-2008: Simulation and seasonal change. Chin. J. Appl. Ecol. 2011, 22, 621-630.

32. Wang, J.; Liu, J.; Shao, Q.; Liu, R.; Fan, J.; Chen, Z. Spatial-temporal patterns of net primary productivity for 1988-2004 based on GLOPEM-CEVSA model in the "Three-river Headwaters" region of Qinghai province, China. Chin. J. Plant Ecol. 2009, 33, 254-269.

33. Tucker, C.J.; Pinzon, J.E.; Brown, M.E.; Slayback, D.A.; Pak, E.W.; Mahoney, R.; Vermote, E.F.; El Saleous, N. An extended AVHRR 8-km NDVI dataset compatible with MODIS and SPOT vegetation NDVI data. Int. J. Remote Sens. 2005, 26, 4485-4498.

34. Sellers, P.J. Canopy reflectance, photosynthesis and transpiration. Int. J. Remote Sens. 1985, 6, 1335-1372.

35. Sellers, P.J.; Tucker, C.J.; Collatz, G.J.; Los, S.O.; Justice, C.O.; Dazlich, D.A.; Randall, D.A. A revised land surface parameterization (SiB2) for atmospheric GCMS. Part II: The generation of global fields of terrestrial biophysical parameters from satellite data. J. Clim. 1996, 9, 706-737.

36. Myneni, R.B. "Special Issue Monitoring Global Vegetation with AVHRR NDVI3g Data (1981-2011)". Available online: http://www.mdpi.com/journal/remotesensing/special_issues/ monitoring_global (accessed on 20 March 2013).

37. Zeng, F.-W.; Collatz, G.J.; Pinzon, J.E.; Ivanoff, A. Evaluating and quantifying the climate-driven interannual variability in global inventory modeling and mapping studies (GIMMS) normalized difference vegetation index (NDVI3g) at global scales. Remote Sens. 2013, 5, 3918-3950.

38. Monteith, J.; Moss, C. Climate and the efficiency of crop production in Britain [and discussion]. Philos. Trans. R. Soc. Lond. Ser. B Biol. Sci. 1977, 281, 277-294.

39. Monteith, J. Solar radiation and productivity in tropical ecosystems. J. Appl. Ecol. 1972, 747-766.

40. Goetz, S.J.; Prince, S.D. Modelling terrestrial carbon exchange and storage: Evidence and implications of functional convergence in light-use efficiency. Adv. Ecol. Res. 1999, 28, 57-92.

41. Goetz, S.J.; Prince, S.D.; Small, J.; Gleason, A.C.R. Interannual variability of global terrestrial primary production: Results of a model driven with satellite observations. J. Geophys. Res. 2000, 105, 20077-20091.

42. Goetz, S.J.; Prince, S.D.; Goward, S.N.; Thawley, M.M.; Small, J. Satellite remote sensing of primary production: An improved production efficiency modeling approach. Ecol. Model. 1999, $122,239-255$.

43. Cao, M.K.; Prince, S.D.; Small, J.; Goetz, S.J. Remotely sensed interannual variations and trends in terestrial net primary productivity 1981-2000. Ecosystems 2004, 7, 233-242.

44. Cao, M.; Woodward, F.I. Dynamic responses of terrestrial ecosystem carbon cycling to global climate change. Nature 1998, 393, 249-252.

45. Cao, M.; Woodward, F.I. Net primary and ecosystem production and carbon stocks of terrestrial ecosystems and their response to climate change. Glob. Chang. Biol. 1998, 4, 185-198.

46. Cao, M.; Prince, S.; Tao, B.; Small, J.; Li, K. Regional pattern and interannual variations in global terrestrial carbon uptake in response to changes in climate and atmospheric $\mathrm{CO}_{2}$. Tellus $B \mathbf{2 0 0 5}$, 57, 210-217. 
47. Collatz, G.; Ball, J.; Grivet, C.; Berry, J. Physiological and environmental regulation of stomatal conductance, photosynthesis and transpiration: A model that includes a laminar boundary layer. Agric. For. Meteorol. 1991, 54, 107-136.

48. Raich, J.W.; Rastetter, E.B.; Melillo, J.M.; Kicklighter, D.W.; Steudler, P.A.; Peterson, B.J.; Grace, A.L.; Moore, B.; Vorosmarty, C.J. Potential net primary productivity in South America: Application of a global model. Ecol. Appl. 1991, 1, 399-429.

49. Zhao, M.; Running, S.W. Drought-induced reduction in global terrestrial net primary production from 2000 through 2009. Science 2010, 329, 940-943.

50. Zhao, M.; Running, S.W.; Nemani, R.R. Sensitivity of Moderate Resolution Imaging Spectroradiometer (MODIS) terrestrial primary production to the accuracy of meteorological reanalyses. J. Geophys. Res. Biogeosci. 2006, 111, doi:10.1029/2004JG000004.

51. Kanamitsu, M.; Ebisuzaki, W.; Woollen, J.; Yang, S.-K.; Hnilo, J.J.; Fiorino, M.; Potter, G.L. NCEP-DOE AMIP-II Reanalysis (R-2). Bull. Am. Meteorol. Soc. 2002, 83, 1631-1643.

52. Allen, R.G.; Food and Agriculture Organization of the United Nations. Chapter 3: Meteorological Data. In Crop Evapotranspiration: Guidelines for Computing Crop Water Requirements; Food and Agriculture Organization of the United Nations: Rome, Italy, 1998; pp. 33-36.

53. Hutchinson, M. ANUSPLIN Version 4.2; Centre for Resource and Environmental Studies, Australian National University: Canberra, Australia, 2001.

54. Yatagai, A.; Kamiguchi, K.; Arakawa, O.; Hamada, A.; Yasutomi, N.; Kitoh, A. APHRODITE: Constructing a long-term daily gridded precipitation dataset for Asia based on a dense network of rain gauges. Bull. Am. Meteorol. Soc. 2012, 93, 1401-1415.

55. Los, S.O. Linkages between Global Vegetation and Climate: An Analysis Based on NOAA Advanced very High Resolution Radiometer Data; 016049527X; National Aeronautics and Space Administration, Goodard Space Flight Center: Greenbelt, MD, USA, 1998.

56. Matlab, R.V. R2011b; The Mathworks Inc.: Natick, MA, USA.

57. Myneni, R.; Hoffman, S.; Knyazikhin, Y.; Privette, J.; Glassy, J.; Tian, Y.; Wang, Y.; Song, X.; Zhang, Y.; Smith, G. Global products of vegetation leaf area and fraction absorbed PAR from year one of MODIS data. Remote Sens. Environ. 2002, 83, 214-231.

58. Myneni, R.; Ramakrishna, R.; Nemani, R.; Running, S. Estimation of global leaf area index and absorbed PAR using radiative transfer models. IEEE Trans. Geosci. Remote Sens. 1997, 35, 1380-1393.

59. Knyazikhin, Y.; Martonchik, J.; Myneni, R.; Diner, D.; Running, S. Synergistic algorithm for estimating vegetation canopy leaf area index and fraction of absorbed photosynthetically active radiation from MODIS and MISR data. J. Geophys. Res. 1998, 103, 32257-32276.

60. Privette, J.L.; Myneni, R.B.; Knyazikhin, Y.; Mukelabai, M.; Roberts, G.; Tian, Y.; Wang, Y.; Leblanc, S.G. Early spatial and temporal validation of MODIS LAI product in the Southern Africa Kalahari. Remote Sens. Environ. 2002, 83, 232-243.

61. Tian, Y.; Wang, Y.; Zhang, Y.; Knyazikhin, Y.; Bogaert, J.; Myneni, R. Radiative transfer based scaling of LAI retrievals from reflectance data of different resolutions. Remote Sens. Environ. 2003, 84, 143-159.

62. Jönsson, P.; Eklundh, L. TIMESAT -A program for analyzing time-series of satellite sensor data. Comput. Geosci. 2004, 30, 833-845. 
63. Eklundha, L.; Jönssonb, P. TIMESAT 3.1 Software Manual; Lund University: Lund, Sweden, 2012.

64. Friedl, M.A.; McIver, D.K.; Hodges, J.C.; Zhang, X.; Muchoney, D.; Strahler, A.H.; Woodcock, C.E.; Gopal, S.; Schneider, A.; Cooper, A. Global land cover mapping from MODIS: Algorithms and early results. Remote Sens. Environ. 2002, 83, 287-302.

65. Liu, Y.F.; Song, X.; Yu, G.R.; Sun, X.M.; Wen, X.F.; Chen, Y.R. Seasonal variation of $\mathrm{CO}_{2}$ flux and its environmental factors in evergreen coniferous plantation. Sci. China Ser. D 2005, $48,123-132$.

66. Wen, X.; Yu, G.; Sun, X.; Liu, Y. Turbulence flux measurement above the overstory of a subtropical Pinus plantation over the hilly region in Southeastern China. Sci. China Ser. D 2005, 48, 63-73.

67. Yan, J.; Liu, X.; Tang, X.; Yu, G.; Zhang, L.; Chen, Q.; Li, K. Substantial amounts of carbon are sequestered during dry periods in an old-growth subtropical forest in South China. J. For. Res. 2013, 18, 21-30.

68. Yan, J.; Zhang, Y.; Yu, G.; Zhou, G.; Zhang, L.; Li, K.; Tan, Z.; Sha, L. Seasonal and inter-annual variations in net ecosystem exchange of two old-growth forests in Southern China. Agric. For. Meteorol. 2013.

69. Zhang, Y.; Tan, Z.; Song, Q.; Yu, G.; Sun, X. Respiration controls the unexpected seasonal pattern of carbon flux in an Asian tropical rain forest. Atmos. Environ. 2010, 44, 3886-3893.

70. Hirata, R.; Saigusa, N.; Yamamoto, S.; Ohtani, Y.; Ide, R.; Asanuma, J.; Gamo, M.; Hirano, T.; Kondo, H.; Kosugi, Y. Spatial distribution of carbon balance in forest ecosystems across East Asia. Agric. For. Meteorol. 2008, 148, 761-775.

71. Saigusa, N.; Yamamoto, S.; Hirata, R.; Ohtani, Y.; Ide, R.; Asanuma, J.; Gamo, M.; Hirano, T.; Kondo, H.; Kosugi, Y. Temporal and spatial variations in the seasonal patterns of $\mathrm{CO}_{2}$ flux in boreal, temperate, and tropical forests in East Asia. Agric. For. Meteorol. 2008, 148, 700-713.

72. Yamamoto, S.; Saigusa, N.; Murayama, S.; Gamo, M.; Ohtani, Y.; Kosugi, Y.; Tani, M. Synthetic Analysis of the $\mathrm{CO}_{2}$ Fluxes at Various Forests in East Asia. In Plant Responses to Air Pollution and Global Change; Omasa, K., Nouchi, I., Kok, L., Eds.; Springer: Tokyo, Japan, 2005; pp. 215-225.

73. Hirano, T.; Segah, H.; Kusin, K.; Limin, S.; Takahashi, H.; Osaki, M. Effects of disturbances on the carbon balance of tropical peat swamp forests. Glob. Chang. Biol. 2012, 18, 3410-3422.

74. Hirano, T.; Kusin, K.; Limin, S.; Osaki, M. Carbon dioxide emissions through oxidative peat decomposition on a burnt tropical peatland. Glob. Chang. Biol. 2013, 20, 555-565.

75. Song, X.; Yu, G.; Liu, Y.; Sun, X.; Ren, C.; Wen, X. Comparison of flux measurement by open-path and close-path eddy covariance systems. Sci. China Ser. D 2005, 48, 174-184.

76. Song, X.; Liu, Y.; Xu, X.; Yu, G.; Wen, X. Comparison study on carbon dioxide, water and heat fluxes of the forest ecosystem in red earth hilly zone over winter and spring. Resour. Sci. 2004, 26, 96-104.

77. Yang, F. Influences of Land Use on Terrestrial Carbon Cycles in Red Soil Hilly Area of South China: Case Research at Qianyanzhou Experimental Station; Institute of Geographic Sciences and Natural Resources Research, Chinese Academy of Sciences: Beijing, China, 2005.

78. Li, Z.Q.; Yu, G.R.; Wen, X.F.; Zhang, L.M.; Ren, C.Y.; Fu, Y.L. Energy balance closure at ChinaFlux sites. Sci. China Ser. D 2005, 48, 151-162. 
79. Yu, G.R.; Wen, X.F.; Li, Q.K.; Zhang, L.M.; Ren, C.Y.; Liu, Y.F.; Guan, D.X. Season pattern and response character to environment of sub-tropic and temperature forest ecosystem respiration in China. Sci. China Ser. D 2005, 48, 93-105.

80. Hirano, T.; Segah, H.; Harada, T.; Limin, S.; June, T.; Hirata, R.; Osaki, M. Carbon dioxide balance of a tropical peat swamp forest in Kalimantan, Indonesia. Glob. Chang. Biol. 2007, 13, 412-425.

81. Fensholt, R.; Proud, S.R. Evaluation of Earth Observation based global long term vegetation trends-Comparing GIMMS and MODIS global NDVI time series. Remote Sens. Environ. 2012, $119,131-147$.

82. Gibson, L.; Lynam, A.J.; Bradshaw, C.J.A.; He, F.; Bickford, D.P.; Woodruff, D.S.; Bumrungsri, S.; Laurance, W.F. Near-complete extinction of native small mammal fauna 25 years after forest fragmentation. Science 2013, 341, 1508-1510.

83. Chen, J.M.; Mo, G.; Pisek, J.; Liu, J.; Deng, F.; Ishizawa, M.; Chan, D. Effects of foliage clumping on the estimation of global terrestrial gross primary productivity. Glob. Biogeochem. Cycle 2012, 26, doi:10.1029/2010GB003996.

84. Zhu, Z.; Bi, J.; Pan, Y.; Ganguly, S.; Anav, A.; Xu, L.; Samanta, A.; Piao, S.; Nemani, R.; Myneni, R. Global data sets of vegetation leaf area index (LAI)3g and fraction of photosynthetically active radiation (FPAR)3g derived from global inventory modeling and mapping studies (GIMMS) normalized difference vegetation index (NDVI3g) for the period 1981 to 2011. Remote Sens. 2013, 5, 927-948.

85. Turner, D.P.; Ritts, W.D.; Cohen, W.B.; Gower, S.T.; Running, S.W.; Zhao, M.S.; Costa, M.H.; Kirschbaum, A.A.; Ham, J.M.; Saleska, S.R.; et al. Evaluation of MODIS NPP and GPP products across multiple biomes. Remote Sens. Environ. 2006, 102, 282-292.

86. Serbin, S.P.; Ahl, D.E.; Gower, S.T. Spatial and temporal validation of the MODIS LAI and FPAR products across a boreal forest wildfire chronosequence. Remote Sens. Environ. 2013, 133, 71-84.

87. Eklundha, L.; Jönssonb, P. Timesat 3.0 Software Manual; Lund University: Lund, Sweden, 2010.

88. Hird, J.N.; McDermid, G.J. Noise reduction of NDVI time series: An empirical comparison of selected techniques. Remote Sens. Environ. 2009, 113, 248-258.

89. Schubert, P.; Lagergren, F.; Aurela, M.; Christensen, T.; Grelle, A.; Heliasz, M.; Klemedtsson, L.; Lindroth, A.; Pilegaard, K.; Vesala, T.; et al. Modeling GPP in the Nordic forest landscape with MODIS time series data-Comparison with the MODIS GPP product. Remote Sens. Environ. 2012, 126, 136-147.

90. Huete, A.R.; Restrepo-Coupe, N.; Ratana, P.; Didan, K.; Saleska, S.R.; Ichii, K.; Panuthai, S.; Gamo, M. Multiple site tower flux and remote sensing comparisons of tropical forest dynamics in Monsoon Asia. Agric. For. Meteorol. 2008, 148, 748-760. 


\section{Appendix}

\section{Potential Light Use Efficiency}

The potential, gross $\varepsilon$ was calculated considering $C 3$ and $C 4$ plant photosynthetic differences and a temperature adjustment proposed by Cao et al. [22,43]:

$$
\text { Plue }=\left(\left(\varepsilon_{C 4} \times P_{C 4}\right)+\left(\varepsilon_{C 3} \times\left(1-P_{C 4}\right)\right)\right)
$$

where $\varepsilon_{C 3}$ and $\varepsilon_{C 4}$ were potential light use efficiency for $C 3$ and $C 4$ plants and $P_{C 4}$ was the proportion of $C 4$ plants. For $C 4, \varepsilon$ does not depend on temperature and has a value of $2.76 \mathrm{~g} \cdot \mathrm{MJ}^{-1}$. The value of $\varepsilon$ for $C 3$ plants was calculated from the quantum yield, the $\mathrm{CO}_{2}$ photocompensation point, internal leaf $\mathrm{CO}_{2}$ concentration and the $\mathrm{CO}_{2} / \mathrm{O}_{2}$ specificity ratio [22,47]:

$$
\begin{gathered}
\varepsilon_{C 3}=55.2 \alpha \\
\alpha=0.08\left(\frac{P_{i}-\Gamma^{*}}{P_{i}+2 \Gamma^{*}}\right) \\
\Gamma^{*}=\frac{O_{i}}{2 \tau} \\
\tau=2600 \times 0.57^{\left(\frac{T a-20}{10}\right)}
\end{gathered}
$$

The proportion of $\mathrm{C} 4$ plants at any point was modelled with climatological mean air temperature as follows:

$$
P_{C 4}=\frac{1}{1+\exp [-0.5 \times(T a-22)]}
$$

A biomass check was used to prevent the $C 4$ pathway being selected in forested regions by setting a threshold biomass $<2 \mathrm{~kg} \mathrm{~m}^{-2}$.

(C) 2014 by the authors; licensee MDPI, Basel, Switzerland. This article is an open access article distributed under the terms and conditions of the Creative Commons Attribution license (http://creativecommons.org/licenses/by/3.0/). 